\title{
Mitochondrial DNA Variation Is an Indicator of Austronesian Influence in Island Melanesia
}

\author{
D. ANDREW MERRIWETHER, ${ }^{*}$ JONATHAN S. FRIEDLAENDER, ${ }^{2}$ \\ JOSE MEDIAVILLA, ${ }^{3}$ CHARLES MGONE, ${ }^{4}$ FRED GENTZ, ${ }^{2}$ \\ AND ROBERT E. FERRELL ${ }^{3}$ \\ ${ }^{1}$ Department of Anthropology, University of Michigan, Ann Arbor, \\ Michigan 48109-1382 \\ ${ }^{2}$ Department of Anthropology, Temple University, \\ Philadelphia, Pennsylvania 191222 \\ ${ }^{3}$ Graduate School of Public Health, University of Pittsburgh, \\ Pittsburgh, Pennsylvania 15261 \\ ${ }^{4}$ Institute for Medical Research, Goroka, EHP, Papua New Guinea
}

KEYWORDS Pacific; mtDNA 9 base pair deletion; Oceania; modern human migrations

\begin{abstract}
Past studies have shown a consistent association of a specific set of mitochondrial DNA 9 base pair (bp) deletion haplotypes with Polynesians and their Austronesian-speaking relatives, and the total lack of the deletion in a short series of New Guinea Highlanders. Utilizing plasma and DNA samples from various old laboratory collections, we have extended population screening for the 9-bp deletion into "Island Melanesia," an area notorious for its extreme population variation. While the 9-bp deletion is present in all Austronesian, and many non-Austronesian-speaking groups, it is absent in the more remote non-Austronesian populations in Bougainville and New Britain. These results are consistent with the hypothesis that this deletion was first introduced to this region about 3,500 years ago with the arrival of Austronesian-speaking peoples from the west, but has not yet diffused through all populations there. The pattern cannot be reconciled with the competing hypothesis of a primarily indigenous Melanesian origin for the ancestors of the Polynesians. Although selection clearly has operated on some other genetic systems in this region, both migration and random genetic drift primarily account for the remarkable degree of biological diversity in these small Southwest Pacific populations. Am J Phys Anthropol 110:243-270, 1999. (1999 Wiley-Liss, Inc.
\end{abstract}

"Biologically, it continues to look as if the so-called Papuan and Melanesian peoples are nothing more than fictions created by linguistic taxonomy."

(J.E. Terrell and J. Fagan, 1975, p. 8)

For most of this century, anthropologists have argued about the nature of the associations of human biology, language, and culture. In one instance at least, the ties are undeniably strong. The Polynesians, especially those in the Central and Eastern Pacific, are a remarkably homogeneous human population, consistent with their very similar languages and cultural traditions, and with the archaeological evidence. They are the immediate descendants of a small number of people who lived in a narrowly defined interval of time (between 3,500 and

*Correspondence to: D. Andrew Merriwether, Dept. of Anthropology, University of Michigan, 1020 LSA Building, 500 S. State St., Ann Arbor, MI 48109-1382. E-mail: andym@umich.edu

Received 6 August 1997; accepted 15 June 1999. 
2,000 BP) and space (the islands immediately to the east and southeast of New Guinea). Their biological affinities have consistently suggested a primary, but not exclusive, Asiatic derivation [see Howells (1979), Turner (1990), Froehlich (1987), and Pietrusewsky (1977) for reviews of the biological evidence exclusive of the single gene distributions discussed below, and Houghton (1996) for a contrary view]. The historical linguistic evidence attests to Asian origins even more directly [see Pawley and Green (1973) and Pawley and Ross (1993, 1995)].

Yet how the Southeast Asian ancestors of the Polynesians traveled from the Asian mainland to the first set of uninhabited Pacific islands, and what the nature of their contact was with the diverse peoples already living in the intervening archipelagoes that extended over thousands of kilometers, have been hotly debated. Following an old ethnohistoric argument, some envisioned a rapid migration of seafaring proto-Polynesian ancestors out of Southeast Asia, leapfrogging along the coasts and uninhabited small offshore islands, maintaining their biological and cultural distinctions from the more landdependent populations already there. Bellwood has marshaled considerable archaeological evidence in its favor and summarized this "Out of Asia" hypothesis, with supporting biological and historical linguistic data, in a series of publications (see Bellwood, 1985). He and others argue that food domestication in Asia, and its technological and demographic sequelae, provide the underlying dynamic for this rapid expansion. This hypothesis was also dubbed the "Express Train" model in one popular account (Diamond, 1988).

Critics, most of whom are archaeologists, argue that the Polynesians as well as their language and culture can be derived from the complex nexus of populations that had resided in Island Melanesia for millennia before, without resorting to such an implausible explanation as a long-range migration. They have not denied Asian influences on the Polynesians, but argued these were more diffusions than aspects of a fairly discrete migration - the process covered a longer period, involving complex interactions of people, their trading relations, and the spread of cultural traditions over a large number of comparatively short distances. This has been called the "Indigenous Melanesian Origin," or most recently the "Voyaging Corridor" model of Polynesian origins (Allen, 1984; Terrell and Fagan, 1975; Terrell and Welsch, 1997; White et al., 1988).

Although positions on either side of this argument have been modified to accommodate new discoveries, the debate continues (cf. Spriggs, 1997 for a recent comprehensive migrationist view).

Here we will focus on the distribution of a single particularly informative genetic variant across a densely sampled, very heterogeneous, set of populations in Island Melanesia. This variant - a mitochondrial DNA (mtDNA) 9-bp deletion — has been closely tied to Polynesians and their Austronesian relatives. Except for a short series from New Guinea, however, almost nothing has been reported for this important region.

\section{“The Polynesian mtDNA motif"}

Early surveys among Pacific populations of the mtDNA 9-bp deletion between the genes for cytochrome oxidase (COII) and transfer RNA for lysine (tRNA ${ }^{\mathrm{Lys}}$ ) suggested the deletion served as a marker of Polynesian affinities with Asians. It was not found in the Highlands of Papua New Guinea or among aboriginal Australians (Hertzberg et al., 1989; Stoneking et al., 1990). It is now apparent that the same 9-bp deletion has occurred independently elsewhere a number of times. This is not surprising, as it is part of a short tandem repeat segment. Different haplotype backgrounds of the deletion have been described for African (Soodyall et al., 1996), other Asian (Ballinger et al., 1992; Redd et al., 1995), and also Australian variants (Betty et al., 1996).

One particular deletion haplotype, associated with three substitutions in the mtDNA control region (CR) at positions 16217, 16247, and 16261, is restricted in its distribution to Polynesians and some of their Austronesianspeaking relatives. This haplotype has been called the "Polynesian motif" (Melton et al., 1995; Redd et al., 1995). Except for Madagascar, it is essentially absent in human populations west of Indonesia. The haplotype 
necessarily developed sequentially, one substitution following on top of another. The change at position 16217 occurred on the background of the 9-bp deletion; the change at 16261 followed on that background; and the change at 16247 appeared on that haplotype, so that all substitutions at 16217 are associated with the deletion and the other two substitutions.

The deletion haplotypes that immediately preceded the "Polynesian Motif" are highest in frequency in the corridor from Taiwan south through the Philippines and east Indonesia, with the highest diversity of these haplotypes in Taiwan. Moving eastward from Indonesia through the Pacific (see Table 1 and Fig. 1), the deletion haplotypes increase in frequency until together they approach fixation (Hertzberg et al., 1989; Ballinger et al., 1992; Harihara et al., 1992; Horai et al., 1993; Hagelberg and Clegg, 1993; Hagelberg et al., 1994; Lum et al., 1994; 1998; Lum and Cann, 1998; Sykes et al., 1995). At the same time, the sequence diversity of the associated CR haplotype variants decreases, with the Polynesian motif becoming more common. This pattern would logically follow from: (a) a number of sequentially occurring founder events moving towards the east, and (b) an origin for the "motif" in the Indonesian archipelago (Redd et al., 1995). Redd's analysis of mtDNA pair-wise difference distributions also fits reasonably well with an expansion of peoples in the expected time range suggested by those historical linguists and archaeologists who favor the model of a long-range migration of Austronesian speakers from Southeast Asia/Taiwan.

The archaeological evidence supporting the long range "Out of Asia" argument is summarized in a number of publications (see Bellwood. 1996; Bellwood et al., 1995; Spriggs, 1990, 1996, 1997; Kirch, 1997; Kirch and Hunt, 1988; Green, 1996, 1997; and Galipaud, 1990 for recent treatments). What follows is an outline of their interpretation of the settlement of "Remote Oceania" and "Near Oceania."

\section{The settlement of "Remote Oceania" from the "Lapita homeland"}

Green (1991) has contrasted human settlement strategies and the distribution of re- sources in the Pacific with his distinction of "Near" versus "Remote" Oceania. Near Oceania comprises New Guinea, the Bismarcks and Admiralties, and the western and central Solomon Islands. People could sail from Southeast Asia through this region without ever entirely losing sight of land, and clearly have occupied this area for tens of thousands of years. Remote Oceania includes the more scattered, smaller islands in the further reaches of the Pacific - Polynesia, Micronesia, and also Fiji, New Caledonia, Vanuatu, and the southeastern Solomon Islands. The immediate forebears of the Polynesians were almost certainly the first group to undertake successfully the multipleday colonizing voyages required to reach these widely dispersed islands. Plant and animal variation decreases sharply from Near to Remote Oceania, as well, so that people moving into Remote Oceania had to deal with ecological impoverishment.

According to the migrationists, the major sequence of events in the human settlement of Remote Oceania has the following general outline:

1. About 3,500 years ago, Lapita, a new archaeological horizon with a novel and sophisticated ceramic tradition, appears without identifiable local antecedents in the New Britain/New Ireland area (the Bismarck Archipelago). It is argued that Lapita is a fully developed, intrusive cultural complex. The associated array of fishhooks, shell ornaments and tools is far more diverse than anything preceding it in this region, and the evidence for an associated long-distance trading network was also something quite new. There is linguistic evidence for only a single language entering this region (ProtoOceanic) ancestral to the more than 400 Oceanic (Austronesian) languages of Polynesia, Island Melanesia, and most of Micronesia, arranged in nine high order subgroups of approximately the same degree of distinction (Pawley and Ross, 1995). All the languages of Polynesia along with those of Fiji and Rotuma form a single subgroup (Central Pacific). Central Pacific is comparable in distinctiveness to Nuclear Micronesian, and each of 
TABLE 1. Other reported Asian and Pacific mtDNA 9 bp deletion frequencies (names are taken from references)

\begin{tabular}{|c|c|c|c|c|c|}
\hline $\begin{array}{l}\text { Map } \\
\text { No. }{ }^{1}\end{array}$ & Population & $\begin{array}{l}\text { Sample } \\
\text { size }\end{array}$ & $\begin{array}{l}\text { No. } \\
\text { deleted }\end{array}$ & $\begin{array}{c}\% \\
\text { Deleted }\end{array}$ & Reference \\
\hline & South Asia & & & & \\
\hline 81 & Pakistan & 76 & 0 & 0 & Melton et al. (1995) \\
\hline 80 & North India (Sikh) & 47 & 0 & 0 & Melton et al. (1995) \\
\hline 79 & South India & 75 & 6 & 8 & Melton et al. (1995) \\
\hline 78 & Vedda & 20 & 0 & 0 & Harihara et al. (1992) \\
\hline \multirow[t]{2}{*}{77} & Bangladesh & 31 & 0 & 0 & Melton et al. (1995) \\
\hline & Australia & & & & \\
\hline 33 & Australia & 21 & 0 & 0 & Stoneking et al. (submitted) \\
\hline 32 & Australian Aborigine & 12 & 0 & 0 & Lum and Cann. (1998) \\
\hline 32 & Australia & 31 & 0 & 0 & Hertzberg et al. (1989) \\
\hline $32 \mathrm{a}$ & $\begin{array}{l}\text { Kimberly region, Western } \\
\text { Australia }\end{array}$ & 64 & 2 & 3.1 & Betty et al. (1996) \\
\hline $32 \mathrm{~b}$ & $\begin{array}{l}\text { Western Desert, Western } \\
\text { Australia }\end{array}$ & 92 & 2 & 2.2 & Betty et al. (1996) \\
\hline $32 \mathrm{c}$ & $\begin{array}{l}\text { Tropical North, Northern } \\
\text { Territory, Australia }\end{array}$ & 85 & 0 & 0 & Betty et al. (1996) \\
\hline \multirow[t]{3}{*}{$32 \mathrm{~d}$} & $\begin{array}{l}\text { Central Desert, Northern } \\
\text { Territory, Australia }\end{array}$ & 49 & 0 & 0 & Betty et al. (1996) \\
\hline & Total Australia & 354 & 4 & 1.1 & \\
\hline & Papua New Guinea & & & & \\
\hline 31 & $\begin{array}{l}\text { Papua New Guinea High- } \\
\text { lands }\end{array}$ & 3 & 0 & 0 & Lum et al. (1994) \\
\hline $31 \mathrm{a}$ & Papua New Guinea & 12 & 0 & 0 & Lum and Cann. (1998) \\
\hline 30 & $\begin{array}{l}\text { Highland Papua New } \\
\text { Guinea (Southern High- } \\
\text { lands: Lake } \\
\text { Kopiago + Erave) }\end{array}$ & 94 & 0 & 0 & $\begin{array}{l}\text { Stoneking and WIlson (1989); } \\
\text { Hertzberg et al. (1989) }\end{array}$ \\
\hline 29 & $\begin{array}{l}\text { Coastal Papua New Guinea } \\
\text { (Madang) }\end{array}$ & 123 & 30 & 24.4 & $\begin{array}{l}\text { Stoneking and WIlson (1989); } \\
\text { Hertzberg et al. (1989) }\end{array}$ \\
\hline \multirow[t]{2}{*}{28} & Papua New Guinea & 114 & 50 & 44 & Sykes et al. (1995) \\
\hline & Total Papua New Guinea & 346 & 80 & 23.1 & \\
\hline 94 & Nortneast Asia & & & & Harihare ot ol (1092) \\
\hline 93 & Ainu & 51 & 1 & 2 & Harihara et al. (1992) \\
\hline $\begin{array}{l}90 \\
92\end{array}$ & & 63 & 12 & 19 & Harihara et al. (1992) \\
\hline & Japan & 116 & 19 & 16.4 & Horai and Matsunaga (1986) \\
\hline $92 \mathrm{a}$ & Japan & 32 & 4 & 12.5 & Lum and Cann (1998) \\
\hline 91 & Mainland Japan & 254 & 38 & 15 & Horai (1991a) \\
\hline \multirow[t]{2}{*}{90} & Okinawa & 82 & 4.1 & 5 & Horai et al. (1987) \\
\hline & Total Japanese & 566 & 74.1 & 13.1 & \\
\hline 89 & Korean & 64 & 5 & 7.8 & Harihara et al. (1992) \\
\hline \multirow[t]{3}{*}{88} & Korean & 13 & 2 & 15.4 & Ballinger et al. (1992) \\
\hline & Total Koreans & 77 & 7 & 9.1 & \\
\hline & Central/Southeast Asia & & & & \\
\hline 73 & "East Asian" & 34 & 6 & 17.6 & Cann et al. (1987) \\
\hline 76 & Tibetan & 54 & 3 & 5.6 & Torroni et al. (1994) \\
\hline 75 & Southern Chinese & 103 & 23 & 22.3 & Melton et al. (1995) \\
\hline $75 \mathrm{a}$ & $\begin{array}{l}\text { Southern Chinese (Can- } \\
\text { tonese) }\end{array}$ & 20 & 4 & 20 & Betty et al. (1996) \\
\hline $75 b$ & Canton China & 25 & 6 & 24 & Lum and Cann (1998) \\
\hline 74 & Malaysian Chinese & 14 & 1 & 7.1 & Ballinger et al. (1992) \\
\hline 68 & Vietnam & 28 & 5 & 17.9 & Ballinger et al. (1992) \\
\hline \multirow[t]{2}{*}{68} & Vietnam & 25 & 8 & 32 & Lum and Cann (1998) \\
\hline & Island Southeast Asia & & & & \\
\hline 87 & Taiwan & 88 & 32 & 36.4 & Sykes et al. (1995) \\
\hline 86 & Taiwanese Han & 20 & 8 & 40 & Ballinger et al. (1992) \\
\hline 85 & Ami & 22 & 10 & 45.5 & Melton et al. (1995) \\
\hline 84 & Atayal & 20 & 5 & 25 & Melton et al. (1995) \\
\hline 83 & Bunum & 19 & 9 & 47.4 & Melton et al. (1995) \\
\hline \multirow[t]{2}{*}{82} & Paiwan & 21 & 10 & 47.6 & Melton et al. (1995) \\
\hline & Total Taiwanese & 190 & 74 & 38.9 & \\
\hline 72 & Ilocana & 97 & 35 & 36.1 & Melton et al. (1995) \\
\hline 71 & Total Filipino & 176 & 70 & 39.8 & Melton et al. (1995) \\
\hline 70 & Philippines & 74 & 20 & 27 & Sykes et al. (1995) \\
\hline $70 \mathrm{a}$ & Phippines & 25 & 10 & 40 & Lum and Cann (1998) \\
\hline \multirow[t]{2}{*}{69} & Negrito & 37 & 34 & 91.9 & Harihara et al. (1992) \\
\hline & Total Philippines & 384 & 159 & 41.4 & \\
\hline
\end{tabular}


TABLE 1. (continued)

\begin{tabular}{|c|c|c|c|c|c|}
\hline $\begin{array}{l}\text { Map } \\
\text { No. }{ }^{1}\end{array}$ & Population & $\begin{array}{c}\text { Sample } \\
\text { size }\end{array}$ & $\begin{array}{c}\text { No. } \\
\text { deleted }\end{array}$ & $\begin{array}{c}\% \\
\text { Deleted }\end{array}$ & Reference \\
\hline $69 \mathrm{~b}$ & Moken, Indian Ocean & 12 & 0 & 0 & Lum and Cann (1998) \\
\hline 67 & Orang Asli & 30 & 11 & 36.7 & Melton et al. (1995) \\
\hline 66 & Malay Aborigines & 32 & 1 & 3.1 & Ballinger et al. (1992) \\
\hline 65 & Malay & 14 & 2 & 14.3 & Ballinger et al. (1992) \\
\hline \multirow[t]{2}{*}{64} & Malay & 81 & $2 \overline{1}$ & 25.9 & Melton et al. (1995) \\
\hline & Total Malay & 127 & 24 & 18.9 & \\
\hline 63 & Borneo & 95 & 23 & 24.2 & Melton et al. (1995) \\
\hline 63 & Borneo & 21 & 8 & 38.1 & Lum and Cann (1998) \\
\hline 62 & Sabah & 74 & 30 & 40.5 & Sykes et al. (1995) \\
\hline \multirow[t]{2}{*}{61} & Sabah Aborigines & 32 & 6 & 18.8 & Ballinger et al. (1992) \\
\hline & Total Borneo & 201 & 59 & 29.4 & \\
\hline 60 & Moluccas & 50 & 8 & 16 & Redd et al. (1995) \\
\hline 59 & Nusa Tenggara & 96 & 23 & 24 & Redd et al. (1995) \\
\hline 58 & Java & 98 & 25 & 25.5 & Melton et al. (1995) \\
\hline 58 & Java & 22 & 6 & 27.3 & Lum and Cann (1998) \\
\hline \multirow[t]{3}{*}{57} & Indonesia & 10 & 6 & 60 & Lum et al. (1994) \\
\hline & Total Indonesia & 254 & 41 & 16.1 & \\
\hline & Remote Oceania & & & & \\
\hline 9 & Vanuatu & 56 & 22 & 39.3 & Sykes et al. (1995) \\
\hline $9 \mathrm{a}$ & Vanuatu & 25 & 3 & 12 & Lum and Cann (1998) \\
\hline 6 & Fiji & 28 & 23 & 82.1 & Hertzberg et al. (1989) \\
\hline 6 & $\mathrm{Fiji}$ & 14 & 9 & 64.3 & Lum and Cann (1998) \\
\hline $27 \mathrm{a}$ & Tolai & 40 & 3 & 7.5 & Hertzberg et al. (1989) \\
\hline 40 & Tonga & 30 & 23 & 76.7 & Hertzberg et al. (1989) \\
\hline 39 & Tonga & 88 & 82 & 93.2 & Sykes et al. (1995) \\
\hline \multirow[t]{2}{*}{38} & Tonga & 2 & 2 & 100 & Lum et al. (1994) \\
\hline & Total Tonga & 120 & 107 & 89.2 & \\
\hline 56 & Marshall Islands & 55 & 53 & 96.4 & Sykes et al. (1995) \\
\hline 56 & Marshall Islands & 31 & 29 & 93.5 & Lum and Cann (1998) \\
\hline 55 & Kapingamarangi & 62 & 62 & 100 & Sykes et al. (1995) \\
\hline 55 & Kapingamarangi & 35 & 35 & 100 & Lum and Cann (1998) \\
\hline 53 & Micronesian & 4 & 3 & 75 & Lum et al. (1994) \\
\hline $53 \mathrm{~b}$ & Outer Yap Islands & 137 & 124 & 90.5 & Lum and Cann (1998) \\
\hline $53 c$ & Nauru & 28 & 25 & 89.3 & Lum and Cann (1998) \\
\hline $53 d$ & Kosrae & 30 & 24 & 80 & Lum and Cann (1998) \\
\hline $53 \mathrm{e}$ & Kiribati & 27 & 20 & 74.1 & Lum and Cann (1998) \\
\hline $53 \mathrm{f}$ & Yap Proper & 70 & 51 & 73 & Lum and Cann (1998) \\
\hline $53 \mathrm{~g}$ & Palau & 134 & 75 & 56 & Lum and Cann (1998) \\
\hline 54 & Pohnpei & 25 & 14 & 56 & Lum and Cann (1998) \\
\hline $53 \mathrm{~h}$ & Marianas & 53 & $\begin{array}{r}14 \\
7\end{array}$ & 13.2 & Lum and Cann (1998) \\
\hline $53 \mathrm{a}$ & Rapa Nui & 14 & 14 & 100 & Lum and Cann (1998) \\
\hline 41 & Niue & 30 & 30 & 100 & Hertzberg et al. (1989) \\
\hline 48 & Samoa & 18 & 16 & 88.9 & Lum et al. (1994) \\
\hline 48 & Samoa & 29 & 25 & 86.2 & Lum and Cann (1998) \\
\hline 47 & Samoa & 24 & 24 & 100 & Redd et al. (1995) \\
\hline 46 & Samoa & 83 & 81 & 97.6 & Sykes et al. (1995) \\
\hline \multirow[t]{2}{*}{45} & Samoa & 30 & 30 & 100 & Hertzberg et al. (1989) \\
\hline & Total Samoa & 228 & 220 & 96.5 & \\
\hline 44 & Cook Islanders & 30 & 26 & 86.7 & Hertzberg et al. (1989) \\
\hline \multirow[t]{2}{*}{43} & Cook Islanders & 224 & 204 & 91.1 & Sykes et al. (1995) \\
\hline & Total Cook Islanders & 254 & 230 & 90.6 & \\
\hline 42 & Tahiti & 114 & 110 & 96.5 & Sykes et al. (1995) \\
\hline 36 & Australs & 68 & 65 & 95.6 & Sykes et al. (1995) \\
\hline 51 & Marquesas & 47 & 41 & 87.2 & Sykes et al. (1995) \\
\hline 52 & Hawaii & 25 & 23 & 92 & Lum et al. (1994) \\
\hline 52 & Hawaii & 28 & 27 & 96.4 & Lum and Cann (1998) \\
\hline 35 & Aoteoroa & 31 & 29 & 93.5 & Sykes et al. (1995) \\
\hline \multirow[t]{2}{*}{$\begin{array}{l}50 \\
34\end{array}$} & Maori & 30 & 30 & 100 & Hertzberg et al. (1989) \\
\hline & Total New Zealand & 61 & 59 & 96.7 & \\
\hline 37 & Easter Island & 12 & 12 & 100 & Hagelberg et al. (1994) \\
\hline
\end{tabular}

${ }^{1}$ See Fig. 1 for map numbers. 
the seven very localized subgroupings in Island Melanesia [Admiralty Islands, St. Matthias Islands, Western Oceanic, Southeast Solomonic, North/Central Vanuatu, South Vanuatu, and Southern Oceanic (New Caledonia)]. See Pawley and Ross (1995) for maps.

2. By some 300-400 years later, these people and their associated cultural complex had spread from the Bismarcks over 4,500 $\mathrm{km}$ - taking the first step into Remote Oceania (the Reef/Santa Cruz region in the southeastern Solomons), and establishing trading networks and habitation sites across Vanuatu, New Caledonia, Fiji, Tonga and Samoa. It was in the Tonga/Samoa area that identifiable Polynesian culture developed directly from these Lapita antecedents over the next millennium, largely in isolation. One missing piece of the archaeological puzzle relevant to our genetic survey is the apparent lack of bona fide Lapita sites in Solomon Islands except for the Reef/ Santa Cruz group and Buka Island. Possible indicators of early Austronesianassociated intrusion or influence in the central Solomons date only to 2,0002,600 BP, with the appearance of plain pottery in Santa Ana and New Georgia (Green, personal communication). Spriggs (1997) suggests a widespread Late Lapita or immediately Post-Lapita ceramic tradition exists in the Western Solomons, indicated by finds in intertidal flats of barrier islands and on New Georgia and Vella Lavella proper.

3. Descendant Polynesian populations beginning about a thousand years later (2,000 years ago) accomplished the first settlement of central Polynesia (Tahiti, the Marquesas, Cooks, etc.).

4. The subsequent, even more distant, colonizations followed from this Central Pacific base to Rapa Nui (Easter Island) by 500 A.D, Hawaii by 600 A.D., and Aotearoa (New Zealand) by 1100 A.D .

5. Initial Micronesian settlement was accomplished in two separate but roughly contemporaneous movements about 3,500 years ago - one northward from the Lapita center in Island Melanesia and the other eastward from Island Southeast Asia (Bellwood, 1989).

This picture of a homogeneous population migration expanding away from its western Pacific origin over a discrete time interval should not be taken to imply that their ancestors were already Polynesian in language, culture, and biology when they moved beyond the Lapita homeland in the Bismarcks. The archaeological record suggests change and development over the sequence there, with evidence of some borrowing from the peoples already living in Near Oceania.

\section{Earlier prehistory in "Near Oceania" - the sequence prior to Lapita}

The archaeological record of human settlement in the region of New Guinea and the islands immediately to the east and southeast now extends back over a long period, although the early sites are scanty both in number and material remains. Before the appearance of Lapita, there is evidence for a series of small, scattered populations through the region, likely subject to considerable malaria (vivax) pressure.

The specific sequence of early human settlement here has the following outline (following Spriggs, 1997; Kirch, 1997; and also Allen,1996):

1. By at least 40,000 years ago, and possibly considerably earlier (Roberts et al., 1994), modern humans moved across the narrow sea barriers of about $90 \mathrm{~km}$ that had separated Pleistocene Southeast Asia from the land mass of Australia/New Guinea. By 35,000 BP, people had occupied almost every ecological zone in the region as well as the near offshore islands including interior New Britain (Pavlides and Gosden, 1994) and New Ireland (Allen, 1996).

2. By 29,000 years ago, people had crossed the not insignificant $180 \mathrm{~km}$ of ocean between New Ireland and Buka/Bougainville (with a few low-lying islands between) and presumably the rest of the Solomons Archipelago (Wickler and Spriggs, 1988; Irwin, 1992). Bougainville and the Western Solomons were all one large island during the terminal stages of the Pleistocene, when sea levels were 
considerably lower. The sites from this early period in Near Oceania suggest only sporadic occupation, involving small groups of mobile, broad-spectrum foragers, with little or no change until about $20,000 \mathrm{BP}$. In the following period of lower sea levels, Allen (1966) believes there are some indications of developing trade connections within the Bismarcks.

3. From 10,000 BP, more sites were occupied in New Ireland and elsewhere in the vicinity, and contact between the Bismarcks and north Solomons may have become more commonplace. However, rather little about this period is well established. While some "indigenist" archaeologists have inferred considerable local development in sailing, trade, and subsistence economy, others suggest that very little changed prior to the appearance of Lapita (Spriggs, 1997). Whichever interpretation is correct, considerable diversity in biology would be an expected outcome in such a small, diverse, and relatively isolated set of populations.

\section{The post-Lapita sequence in Near Oceania-3,500 BP to the present}

The post-Lapita period is less well understood than either the Lapita period itself or the last few hundred years. Archaeological materials are scarce post-Lapita, and there is no distinctive pottery tradition as before. There are suggestions of rearranged trading networks in different regions, but with a tendency towards contraction and smallscale population movements. Spriggs' (1997, p. 185-186) summary follows: "The Lapita culture was never a completely homogeneous entity, and did not directly impinge on all populations in the region. Its indirect effect, however ... was much more general. By about 2500-2000 BP (Island Melanesia) was as homogeneous as it was ever going to get, with much of the material culture in daily use similar from one end of the region to the other ... This relatively unified cultural region subsequently underwent diversification as the tenuous threads of connection were severed... Trade networks contracted. . . As language followed its natural tendency to diverge, what had been essentially a mutually intelligible (Austronesian) dialect chain from the Bismarcks through to New Caledonia broke down into a myriad of languages. . . The cultural diversity for which the region is celebrated is a product largely of the last 2000 years of contingent history and cultural drift, tempered by the different circumstances in which groups found themselves in culture contact situations over the last several hundred years. .."

\section{Corroborative data}

A considerable part of the long-range migration case rests on historical linguistic evidence. Many lexical reconstructions for Proto-Austronesian (PAN) are consistent with archaeological finds from Taiwan from before 5,000 BP and from the Hemudu site near the mouth of the Yangzi River 1,000 years earlier. Historical linguists have linked Austronesian ultimately with other southern Asian languages (either Thai-Kadai or Austroasiatic - see Blust, 1996b; Benedict 1975; Bellwood, 1996) with homelands suggested in the vicinity of the upper reaches of the Yangzi River Valley about 8,000-8,500 BP. The importance of this argument in the current context is the increased certainty of a mainland Asiatic locale (as opposed to a Near Oceanic one) being the Austronesian homeland.

Other genetic studies have also indicated ties of varying strengths to Asia. The $G m^{\text {fa:b }}$ allele, which has its highest frequency in Thailand and Southeast Asia, has been found in all Austronesian populations tested (Schanfield, 1977). While it is present as well in non-Austronesian populations in Island Melanesia and some areas of New Guinea near to Austronesian settlements, it is still missing among most non-Austronesian speakers New Guinea, and all of Australian aboriginal populations (Schanfield, 1977). The variants in the alpha globin gene cluster indicate not only a primary relationship of Polynesians with Southeast Asians but also a secondary and subsequent relationship with "Melanesians" [as represented by a heterogeneous set of contemporary populations from Papua New Guinea and Vanuatu (cf. Martinson et al., 1994; Martinson, 1996]. Hill et al. (1989) had specified 
northern Island Melanesia, as opposed to New Guinea, as the area of genetic contact and exchange on the basis of alpha globin haplotype variants in Polynesians.

\section{Contrary arguments}

Critics point to some evidence that begs the migrationist case. Any list would have to include the following:

1. A short series of skeletal samples from Lapita sites on Watom Island in the Bismarcks and on Fiji has yielded no positive 9-bp mtDNA identifications (Hagelberg and Clegg, 1993). However, Kirch (1997) finds this result inconclusive, given the very late or even postLapita age of the materials tested; they were too late to have been part of "the bundle" and may even be part of subsequent population overlays. There is also the very real possibility that the recovered mtDNA fragments were from contaminated sources - an all too common occurrence in ancient DNA PCR analyses.

2. Contact and gene flow of some sort remain a possibility between eastern Polynesian and west coast South American populations (Cann, 1994; Sykes et al., 1995; Hagelberg et al., 1994; Finney, 1996). While Finney suggests return trips between Eastern Polynesia and South America were within the capabilities of Polynesian seafarers, Hagelberg's suggestion is different; the Polynesians and South American native populations may have shared a recent common ancestral source, as indicated by the general similarities in their mtDNA 9-bp deletion haplotypes. However, a common Asiatic origin for both groups is also compatible with this similarity (the haplotypes are not identical). As discussed in Bonatto et al. (1996), this explanation is much more likely (although see Cann and Lum (1996) for a contrary position].

3. If the bundle of the Lapita culture complex with Proto-Oceanic and a set of genetic markers existed in the Bismarcks at a certain time, its western antecedents remain controversial. Bellwood (1985) and others [Kirch 91997, p. 50), and Chang and Goodenough (1996)] have made the case for likely Lapita derivations from Island Southeast Asian ceramic traditions. To the contrary, there are a number of claimed Lapita pottery antecedents in New Guinea, but none are unchallenged and many are not well dated. They are being seen in simple and rather crude pottery on the north coast of New Guinea [cf. Terrell and Welsch (1997), Gorecki et al. (1991), and Swadling et al. (1989)].

4. There are a number of unresolved arguments concerning the antiquity of nonceramic Asian influences in the region and, alternatively, the indigenous development of various innovations. Allen (1996), among others, argued for an early introduction of the domesticated pig, but see Spriggs (1996) for a scenario with a later appearance. Warner (1962) made a case for a New Guinea origin for sugarcane, but Daniels and Daniels (1993) have argued against this. Yen (1992) now argues for indigenous origins of many other domesticates, but Spriggs (1997, p. 84ff) questions even the appearance of developed agriculture in the New Guinea Highlands 9,000 years ago, which had been generally accepted.

\section{Questions}

We intended to address the following specific issues. First, is the deletion haplotype in Island Melanesia Asiatic in origin, or is it possibly a local variant? If it appears to have been introduced from Asia, could there be non-Austronesian populations that still lack it, 3,500 years or more after its introduction, as in New Guinea? Also, are there any Austronesian-speaking populations that lack the marker? Or do all populations in the region, of whatever language affiliation, have the 9-bp deletion to some degree? Can the causes of the extreme genetic variation on Bougainville Island now be identified?

More generally, does the contemporary array of languages in this region reveal anything about the equally complex distribution of biological (genetic) affinities? Is there anything left of the presumed proto-Polynesian "bundle" of genes, language, and culture that the migrationists think arrived in Island Melanesia around 3,500 years ago? If 
so, can one identify a common non-Austronesian genetic bundle or signature of preceding populations? What is the likely role of molecular genetics in studies of population history? Are we left with geographic propinquity as the only significant covariate of genetic variants, artifact distributions, and linguistic relationships?

\section{MATERIALS AND METHODS Population samples}

For this study, we have identified and typed DNA from plasma or buffy coats from over 1,800 maternally unrelated individuals, primarily from Island Melanesian sites. The materials come from existing laboratory collections. We have used unrelated male samples, where possible, to represent maternal lineages in planned Y chromosome comparisons. The samples were tested for up to five polymorphic mtDNA RFLPs (Alu I 10397, Dde I 10394, Hae III 16517, Hae III 16398, Taq I 16261) and the 9-bp intergenic region $\mathrm{V}$ deletion.

The samples, their sizes, language affiliations, and geographic locations and provenience are listed in Tables 1- 3, and in Figures 1, 2, and 3. They cover a substantial number of the remaining non-Austronesian languages spoken in the region, as well as representative languages from seven of the nine high-order subgroups of the Oceanic languages (of Austronesian) recognized by Pawley and Ross (1996); only the Admiralty and St. Matthias Islands subgroups are not represented.

1. New Britain. The Baining, a group from the eastern interior of the island, speak a non-Austronesian language. They are now thought to have originally come to this region from nearby New Ireland, and subsequently have been driven inland by later arriving populations, including the Austronesian-speaking Tolai (Capell, 1967). The dialects within Baining are very diverse, implying considerable differentiation in place. Wurm (1975) placed Baining with the other non-Austronesian languages of New Britain, New Ireland, Bougainville, and the Solomons in a single group he named the East Papuan Phylum, with the suggestion they are remnants of one of the earliest migrants into the entire Australian/New Guinea region. Others are unwilling to recognize the validity of the East Papuan Phylum, suggesting if there was an original relationship, it was so old that any evidence for it has been obliterated (Pawley, personal communication). In fact, Foley (1986) was unwilling to go beyond clustering a few of the non-Austronesian languages of New Guinea in 40 separate families. He emphasized the irregular, nonbifurcating process of language differentiation in these languages. Often neighbors for long periods, they have borrowed extensively from each other, a contrast with the typical Austronesian situation.

The "Kimbe" hospital sample consists of a mixed group of people from north-central and western New Britain. Linguistically this area represents the seam of Western Oceanic languages, and hence its likely homeland, from which expansions occurred to the east and southeast (the Meso-Melanesian group, which includes the Austronesian languages of Bougainville) and to the west (the North New Guinea Cluster). Sparse ceramic finds from recent times suggest modest trade relations with the New Guinea mainland. We have not divided the "Kimbe" sample because of its small size, and because the mtDNA 9-bp deletion appears in both its linguistic subsets. We see no suggestion of a sharp distinction in its frequency. The New Britain materials originate from the Papua New Guinea Institute of Medical Research Collection.

2. Bougainville. The sample coverage is most intense for Bougainville Island, which has the most heterogeneous set of populations east of New Guinea (600 individuals covered, belonging to ten groups, two of which are Austronesian-speaking). The contemporary non-Austronesian languages there form distinctive western and eastern clusters, which may or may not be related. As noted, off-island relationships of these languages are also tentative. The most isolated (non-Austronesian) group in Bougainville is the northwestern one, notably the Aita dialect of Rotokas. This is the most distinctive of Wurm's East Papuan Phylum, with the smallest known set of phonemes of 

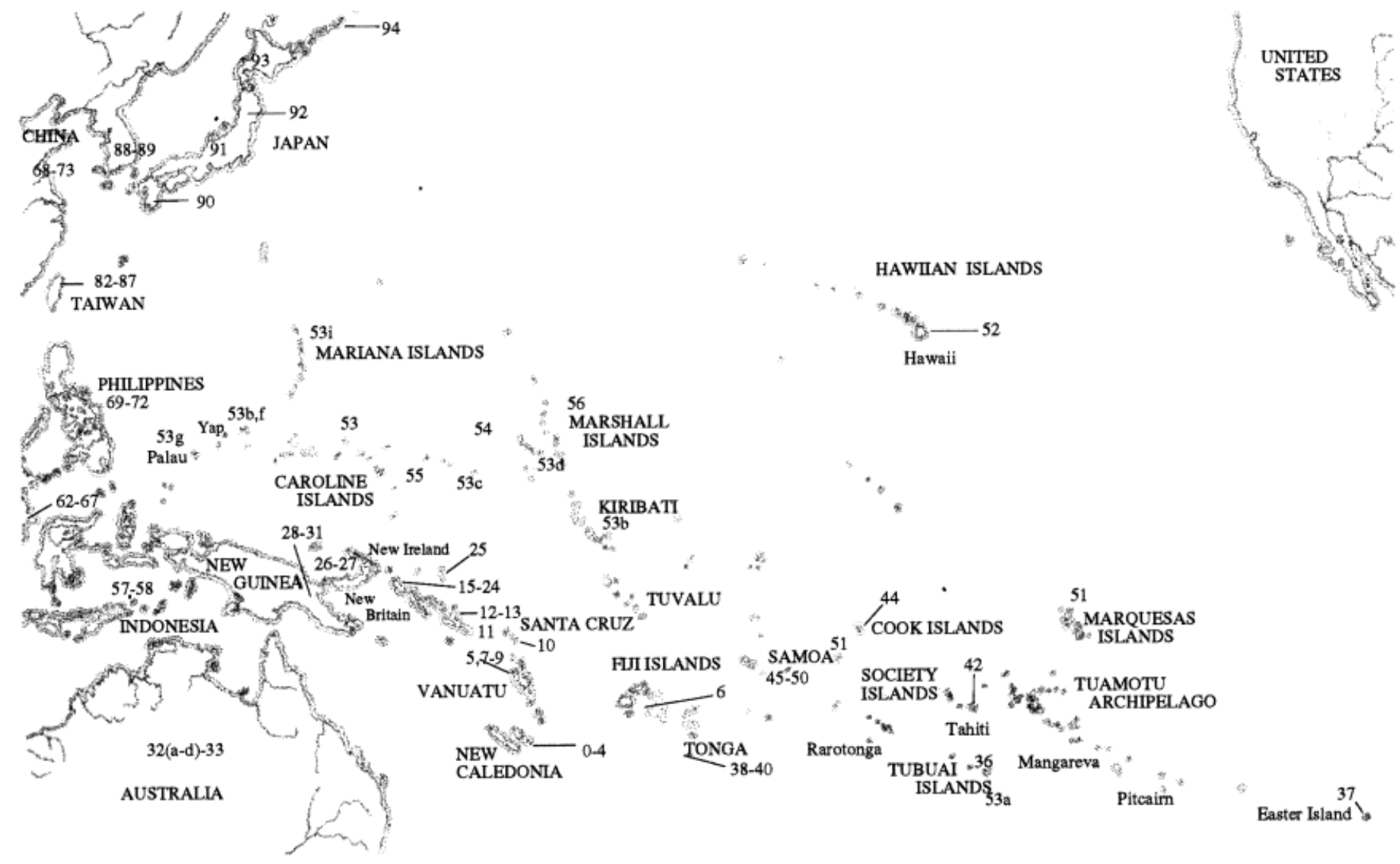

Fig. 1. Map of the locations of the distribution of the mtDNA 9 base pair deletion data in Asian and Pacific populations. Numbers correspond to named populations and frequencies in Tables 1,2 , and 3 . 
TABLE 2. Frequencies of the 9-bp deletion and four RFLP polymorphisms by village using data collected in this study

\begin{tabular}{|c|c|c|c|c|c|c|c|}
\hline $\begin{array}{l}\text { Village or } \\
\text { region }\end{array}$ & Island & $\begin{array}{l}\text { Language } \\
\text { group }\end{array}$ & $\begin{array}{c}\text { 9-bp } \\
\text { deletion }\end{array}$ & $\begin{array}{c}\text { Alu I } \\
10397\end{array}$ & $\begin{array}{l}\text { Dde I } \\
10394\end{array}$ & $\begin{array}{c}\text { Hae III } \\
16398\end{array}$ & $\begin{array}{c}\text { Hae III } \\
16517\end{array}$ \\
\hline Northern mountains & Bougainville & Aita & $\begin{array}{c}0 \% \\
(0 / 36)\end{array}$ & $\begin{array}{l}83.3 \% \\
(50 / 60)\end{array}$ & $\begin{array}{l}83.3 \% \\
(50 / 60)\end{array}$ & $\begin{array}{l}0 \% \\
(0 / 62)\end{array}$ & $\begin{array}{c}6.6 \% \\
(4 / 61)\end{array}$ \\
\hline Neupatol & Bougainville & Aita/Rotokas & $\begin{array}{l}14.3 \% \\
(3 / 21)\end{array}$ & $\begin{array}{c}86.7 \% \\
(13 / 15)\end{array}$ & $\begin{array}{c}81.0 \% \\
(17 / 21)\end{array}$ & $\begin{array}{l}0 \% \\
(0 / 7)\end{array}$ & $\begin{array}{c}44.4 \% \\
(8 / 18)\end{array}$ \\
\hline Okowopaia & Bougainville & Rotokas & $\begin{array}{r}4.0 \% \\
(1 / 25)\end{array}$ & $\begin{array}{l}100.0 \% \\
(14 / 14)\end{array}$ & $\begin{array}{l}100.0 \% \\
(26 / 26)\end{array}$ & $\begin{array}{l}0 \% \\
(0 / 6)\end{array}$ & $\begin{array}{c}65.4 \% \\
(17 / 26)\end{array}$ \\
\hline Kopani & Bougainville & Eivo & $\begin{array}{r}35.0 \% \\
(21 / 60)\end{array}$ & $\begin{array}{c}56.8 \% \\
(25 / 44)\end{array}$ & $\begin{array}{l}66.7 \% \\
(36 / 54)\end{array}$ & $\begin{array}{l}0 \% \\
(0 / 18)\end{array}$ & $\begin{array}{l}53.9 \% \\
(35 / 65)\end{array}$ \\
\hline Kopikiri & Bougainville & Eivo & $\begin{array}{r}61.1 \% \\
(11 / 18)\end{array}$ & $\begin{array}{l}22.2 \% \\
(2 / 9)\end{array}$ & $\begin{array}{l}15.8 \% \\
(3 / 19)\end{array}$ & $\begin{array}{l}0 \% \\
(0 / 6)\end{array}$ & $\begin{array}{c}57.9 \% \\
(11 / 19)\end{array}$ \\
\hline Nasiwawa & Bougainville & Eivo & $\begin{array}{l}29.0 \% \\
(9 / 31)\end{array}$ & $\begin{array}{c}62.5 \% \\
(20 / 32)\end{array}$ & $\begin{array}{c}63.9 \% \\
(23 / 36)\end{array}$ & $\begin{array}{l}0 \% \\
(0 / 10)\end{array}$ & $\begin{array}{c}65.7 \% \\
(23 / 35)\end{array}$ \\
\hline Atamo & Bougainville & Eivo & $\begin{array}{r}68.8 \% \\
(11 / 16)\end{array}$ & $\begin{array}{l}14.3 \% \\
(2 / 14)\end{array}$ & $\begin{array}{l}15.4 \% \\
(2 / 13)\end{array}$ & $\begin{array}{l}0 \% \\
(0 / 15)\end{array}$ & $\begin{array}{c}81.3 \% \\
(26 / 32)\end{array}$ \\
\hline Uruto & Bougainville & $\begin{array}{l}\text { Eivo } \\
\text { Total Eivo }\end{array}$ & $\begin{array}{c}31.3 \% \\
(5 / 16) \\
40.4 \% \\
(57 / 141)\end{array}$ & $\begin{array}{c}60.0 \% \\
(12 / 20) \\
51.3 \% \\
(61 / 119)\end{array}$ & $\begin{array}{c}75.0 \% \\
(18 / 24) \\
56.2 \% \\
(82 / 146)\end{array}$ & $\begin{array}{l}0 \% \\
(0 / 6) \\
0 \% \\
(0 / 55)\end{array}$ & $\begin{array}{c}52.0 \% \\
(13 / 25) \\
61.4 \% \\
(108 / 176)\end{array}$ \\
\hline Kanavito & Bougainville & Simeku & $\begin{array}{l}15.4 \% \\
(4 / 26)\end{array}$ & $\begin{array}{l}77.8 \% \\
(7 / 9)\end{array}$ & $\begin{array}{l}55.6 \% \\
(5 / 9)\end{array}$ & $\begin{array}{l}0 \% \\
(0 / 6)\end{array}$ & $\begin{array}{c}73.1 \% \\
(19 / 26)\end{array}$ \\
\hline Boira & Bougainville & Simeku & $\begin{array}{l}35.7 \% \\
(5 / 14)\end{array}$ & $\begin{array}{l}25.0 \% \\
(2 / 8)\end{array}$ & $\begin{array}{l}25.0 \% \\
(2 / 8)\end{array}$ & $\begin{array}{l}0 \% \\
(0 / 5)\end{array}$ & $\begin{array}{c}94.4 \% \\
(17 / 18)\end{array}$ \\
\hline Korpei & Bougainville & $\begin{array}{l}\text { Simeku } \\
\text { Total Simeku }\end{array}$ & $\begin{array}{r}23.8 \% \\
(10 / 42) \\
23.2 \% \\
(19 / 82)\end{array}$ & $\begin{array}{c}50.0 \% \\
(10 / 20) \\
51.4 \% \\
(19 / 37)\end{array}$ & $\begin{array}{c}50.0 \% \\
(9 / 18) \\
45.7 \% \\
(16 / 35)\end{array}$ & $\begin{array}{l}0 \% \\
(0 / 15) \\
0 \% \\
(0 / 26)\end{array}$ & $\begin{array}{c}80.0 \% \\
(32 / 40) \\
81.0 \% \\
(68 / 84)\end{array}$ \\
\hline Rorovana & Bougainville & Torau & $\begin{array}{r}46.2 \% \\
(18 / 39)\end{array}$ & $\begin{array}{c}53.8 \% \\
(21 / 39)\end{array}$ & $\begin{array}{l}51.3 \% \\
(20 / 39)\end{array}$ & & $\begin{array}{c}72.5 \% \\
(29 / 40)\end{array}$ \\
\hline Arawa & Bougainville & Uruava & $\begin{array}{r}42.9 \% \\
(12 / 28)\end{array}$ & $\begin{array}{l}30.8 \% \\
(8 / 26)\end{array}$ & $\begin{array}{l}28.0 \% \\
(7 / 25)\end{array}$ & $\begin{array}{l}0.0 \% \\
(0 / 2)\end{array}$ & $\begin{array}{c}75.0 \% \\
(21 / 28)\end{array}$ \\
\hline Bairima & Bougainville & Nasioi & $\begin{array}{r}57.9 \% \\
(11 / 19)\end{array}$ & $\begin{array}{l}38.9 \% \\
(7 / 18)\end{array}$ & $\begin{array}{l}27.3 \% \\
(3 / 11)\end{array}$ & & $\begin{array}{c}84.2 \% \\
(16 / 19)\end{array}$ \\
\hline Sieronji & Bougainville & Nasioi & $\begin{array}{l}31.6 \% \\
(6 / 19)\end{array}$ & $\begin{array}{l}63.6 \% \\
(7 / 11)\end{array}$ & $\begin{array}{l}55.6 \% \\
(5 / 9)\end{array}$ & $\begin{array}{l}0 \% \\
(0 / 3)\end{array}$ & $\begin{array}{r}22.2 \% \\
(4 / 18)\end{array}$ \\
\hline Pomowa & Bougainville & Nasioi & $\begin{array}{l}28.1 \% \\
(9 / 32)\end{array}$ & $\begin{array}{c}71.4 \% \\
(15 / 21)\end{array}$ & $\begin{array}{c}71.4 \% \\
(15 / 21)\end{array}$ & & $\begin{array}{c}25.0 \% \\
(8 / 32)\end{array}$ \\
\hline Aropa Valley & Bougainville & $\begin{array}{l}\text { Nasioi } \\
\text { Total Nasioi }\end{array}$ & $\begin{array}{c}66.7 \% \\
(38 / 57) \\
50.4 \% \\
(64 / 127)\end{array}$ & $\begin{array}{c}31.6 \% \\
(24 / 76) \\
42.1 \% \\
(53 / 126)\end{array}$ & $\begin{array}{c}34.6 \% \\
(27 / 78) \\
42.0 \% \\
(50 / 119)\end{array}$ & $\begin{array}{l}0 \% \\
(0 / 58) \\
0 \% \\
(0 / 61)\end{array}$ & $\begin{array}{c}77.3 \% \\
(58 / 75) \\
59.7 \% \\
(86 / 144)\end{array}$ \\
\hline Near Sovele & Bougainville & Nagovisi & $\begin{array}{r}96.1 \% \\
(49 / 51)\end{array}$ & $\begin{array}{c}0 \% \\
(0 / 18)\end{array}$ & $\begin{array}{c}0 \% \\
(0 / 18)\end{array}$ & $\begin{array}{l}0 \% \\
(0 / 46)\end{array}$ & $\begin{array}{c}97.4 \% \\
(76 / 78)\end{array}$ \\
\hline Turungum & Bougainville & Siwai & $\begin{array}{l}40.9 \% \\
(9 / 22)\end{array}$ & $\begin{array}{c}0 \% \\
(0 / 14)\end{array}$ & $\begin{array}{l}36.8 \% \\
(7 / 19)\end{array}$ & $\begin{array}{l}0 \% \\
(0 / 2)\end{array}$ & $\begin{array}{c}86.4 \% \\
(19 / 22)\end{array}$ \\
\hline Mataras & Bougainville & Siwai & $\begin{array}{l}80.0 \% \\
(4 / 5)\end{array}$ & $\begin{array}{l}20.0 \% \\
(4 / 20)\end{array}$ & $\begin{array}{l}21.1 \% \\
(4 / 19)\end{array}$ & $\begin{array}{l}0 \% \\
(0 / 7)\end{array}$ & $\begin{array}{c}86.4 \% \\
(19 / 22)\end{array}$ \\
\hline Moronei & Bougainville & $\begin{array}{l}\text { Siwai } \\
\text { Total Siwai }\end{array}$ & $\begin{array}{r}79.2 \% \\
(19 / 24) \\
62.7 \% \\
(32 / 51)\end{array}$ & $\begin{array}{l}12.0 \% \\
(3 / 25) \\
11.9 \% \\
(7 / 59)\end{array}$ & $\begin{array}{c}20.0 \% \\
(6 / 30) \\
25.0 \% \\
(17 / 68)\end{array}$ & $\begin{array}{l}0 \% \\
(0 / 4) \\
0 \% \\
(0 / 13)\end{array}$ & $\begin{array}{c}93.9 \% \\
(31 / 33) \\
89.6 \% \\
(69 / 77)\end{array}$ \\
\hline Malekula & Vanuatu & & $\begin{array}{l}13.3 \% \\
(2 / 15)\end{array}$ & & & & \\
\hline Malo & Vanuatu & & $\begin{array}{c}49.4 \% \\
(76 / 154)\end{array}$ & & & & \\
\hline Yate & New Caledonia & & $\begin{array}{c}13.3 \% \\
(20 / 150)\end{array}$ & & & & \\
\hline Poindime & New Caledonia & & $\begin{array}{l}21.3 \% \\
(10 / 47)\end{array}$ & & & & \\
\hline Koumac & New Caledonia & & $\begin{array}{r}28.4 \% \\
(23 / 81)\end{array}$ & & & & \\
\hline Noumea & New Caledonia & & $\begin{array}{c}19.0 \% \\
(29 / 153)\end{array}$ & & & & \\
\hline Other & New Caledonia & & $\begin{array}{c}21.7 \% \\
(31 / 143)\end{array}$ & & & & \\
\hline
\end{tabular}


TABLE 3. 9-bp deletion and 4 RFLP site data from this study grouped by language group and by island

\begin{tabular}{|c|c|c|c|c|c|c|c|c|c|c|c|c|}
\hline $\begin{array}{c}\text { Village } \\
\text { or region }\end{array}$ & $\begin{array}{l}\text { Map } \\
\text { no. }^{1}\end{array}$ & Island & $\begin{array}{c}\text { Total } \\
\text { sample }\end{array}$ & $\begin{array}{l}\text { Total } \\
\text { DNA }\end{array}$ & $\begin{array}{l}\text { Samp } \\
\text { type }^{2}\end{array}$ & $\begin{array}{l}\text { Language } \\
\text { group }\end{array}$ & $\begin{array}{c}\text { 9-bp } \\
\text { deletion }\end{array}$ & $\begin{array}{l}\text { Alu I } \\
10397\end{array}$ & $\begin{array}{l}\text { Dde I } \\
10394\end{array}$ & $\begin{array}{c}\text { Hae III } \\
16398\end{array}$ & $\begin{array}{c}\text { Hae III } \\
16517\end{array}$ & $\begin{array}{l}\text { Haplotypes: } \\
\text { N0-N1-D0-D1 }\end{array}$ \\
\hline Baining & 27 & New Britain & 100 & 100 & Cell & Baining & $\begin{array}{l}0 \% \\
(0 / 43)\end{array}$ & & & & & \\
\hline Kimbe & 26 & New Britain & 100 & 100 & Cell & Austronesian & $\begin{array}{l}38.7 \% \\
(12 / 31)\end{array}$ & & & & & \\
\hline $\begin{array}{l}\text { Northern } \\
\text { mountains }\end{array}$ & 24 & Bougainville & 345 & 77 & Plas & Aita & $\begin{array}{l}0 \% \\
(0 / 36)\end{array}$ & $\begin{array}{c}83.3 \% \\
(50 / 60)\end{array}$ & $\begin{array}{c}83.3 \% \\
(50 / 60)\end{array}$ & $\begin{array}{c}0 \% \\
(0 / 62)\end{array}$ & $\begin{array}{r}6.6 \% \\
(4 / 61)\end{array}$ & $\begin{array}{l}15.8 \%-84.2 \%-0 \%-0 \% \\
(6 / 38-32 / 38-0 / 387-0 / 38)\end{array}$ \\
\hline Neupatol & 23 & Bougainville & 116 & 22 & Plas & Aita/Rotokas & $\begin{array}{c}14.3 \% \\
(3 / 21)\end{array}$ & $\begin{array}{c}86.7 \% \\
(13 / 15)\end{array}$ & $\begin{array}{l}81.0 \% \\
(17 / 21)\end{array}$ & $\begin{array}{r}0 \% \\
(0 / 7)\end{array}$ & $\begin{array}{l}44.4 \% \\
(8 / 18)\end{array}$ & $\begin{array}{l}0 \%-85 \%-15 \%-0 \% \\
(0 / 20-17 / 20-3 / 20-0 / 20)\end{array}$ \\
\hline Okowopaia & 22 & Bougainville & 98 & 26 & Plas & Rotokas & $\begin{array}{l}4.0 \% \\
(1 / 25)\end{array}$ & $\begin{array}{l}100.0 \% \\
(14 / 14)\end{array}$ & $\begin{array}{l}100.0 \% \\
(26 / 26)\end{array}$ & $\begin{array}{r}0 \% \\
(0 / 6)\end{array}$ & $\begin{array}{r}65.4 \% \\
(17 / 26)\end{array}$ & $\begin{array}{l}0 \%-96 \%-0 \%-4 \% \\
(0 / 25-24 / 25-0 / 25-1 / 25)\end{array}$ \\
\hline $\begin{array}{l}\text { Atamo, } \\
\text { Kopani, } \\
\text { Koipkiri, } \\
\text { Nasiwawa, } \\
\text { Uruto }\end{array}$ & 21 & Bougainville & 717 & 175 & Plas & Eivo & $\begin{array}{l}40.4 \% \\
(57 / 141)\end{array}$ & $\begin{array}{r}51.3 \% \\
(61 / 119)\end{array}$ & $\begin{array}{r}56.2 \% \\
(82 / 146)\end{array}$ & $\begin{array}{l}0 \% \\
(0 / 55)\end{array}$ & $\begin{array}{c}61.4 \% \\
(108 / 176)\end{array}$ & $\begin{array}{l}6.7 \%-50 \%-39.2 \%-1.7 \% \\
(8 / 120-60 / 120-47 / 120-2 / 120) \\
\quad+3 / 120 \mathrm{~N} / 10397+/ 10394\end{array}$ \\
\hline $\begin{array}{l}\text { Boira, } \\
\text { Kanavito, } \\
\text { Korpei }\end{array}$ & 18 & Bougainville & 507 & 90 & Plas & Simeku & $\begin{array}{l}23.2 \% \\
(19 / 82)\end{array}$ & $\begin{array}{l}51.4 \% \\
(19 / 37)\end{array}$ & $\begin{array}{c}45.7 \% \\
(16 / 35)\end{array}$ & $\begin{array}{c}0 \% \\
(0 / 26)\end{array}$ & $\begin{array}{r}81.0 \% \\
(68 / 84)\end{array}$ & $\begin{array}{l}12.9 \%-22.6 \%-74.2 \%-9.7 \% \\
(4 / 31-7 / 31-23 / 31-3 / 31)\end{array}$ \\
\hline $\begin{array}{l}\text { Aropa V., } \\
\text { Bairima, } \\
\text { Pomowa, } \\
\text { Sieronji }\end{array}$ & 17 & Bougainville & 518 & 172 & $\begin{array}{l}\text { Plas } \\
\text { Cell }\end{array}$ & Nasioi & $\begin{array}{l}50.4 \% \\
(64 / 127)\end{array}$ & $\begin{array}{r}42.1 \% \\
(53 / 126)\end{array}$ & $\begin{array}{r}42.0 \% \\
(50 / 119)\end{array}$ & $\begin{array}{c}0 \% \\
(0 / 61)\end{array}$ & $\begin{array}{l}59.7 \% \\
(86 / 144)\end{array}$ & $\begin{array}{l}5.8 \%-52.3 \%-32.6 \%-2.3 \% \\
(5 / 86-45 / 86-28 / 86-2 / 86)\end{array}$ \\
\hline Arawa & 19 & Bougainville & 139 & 30 & Plas & Uruava & $\begin{array}{l}42.9 \% \\
(12 / 28)\end{array}$ & $\begin{array}{l}30.8 \% \\
(8 / 26)\end{array}$ & $\begin{array}{l}28.0 \% \\
(7 / 25)\end{array}$ & $\begin{array}{l}0.0 \% \\
(0 / 2)\end{array}$ & $\begin{array}{r}75.0 \% \\
(21 / 28)\end{array}$ & $\begin{array}{l}23.1 \%-30.8 \%-46.2 \%-0 \% \\
(6 / 26-8 / 26-12 / 26-0 / 26)\end{array}$ \\
\hline Rorovana & 20 & Bougainville & 289 & 42 & Plas & Torau & $\begin{array}{l}46.2 \% \\
(18 / 39)\end{array}$ & $\begin{array}{l}53.8 \% \\
(21 / 39)\end{array}$ & $\begin{array}{l}51.3 \% \\
(20 / 39)\end{array}$ & & $\begin{array}{r}72.5 \% \\
(29 / 40)\end{array}$ & $\begin{array}{l}10 \%-40 \%-50 \%-0 \% \\
(2 / 20-8 / 20-10 / 20-0 / 20)\end{array}$ \\
\hline near Sovele & 16 & Bougainville & 416 & 68 & Plas & Nagovisi & $\begin{array}{c}96.1 \% \\
(49 / 51)\end{array}$ & $\begin{array}{c}0 \% \\
(0 / 18)\end{array}$ & $\begin{array}{c}0 \% \\
(0 / 18)\end{array}$ & $\begin{array}{c}0 \% \\
(0 / 46)\end{array}$ & & $\begin{array}{l}0 \%-0 \%-100 \%-0 \% \\
(0 / 8-0 / 8-8 / 8-0 / 8)\end{array}$ \\
\hline
\end{tabular}




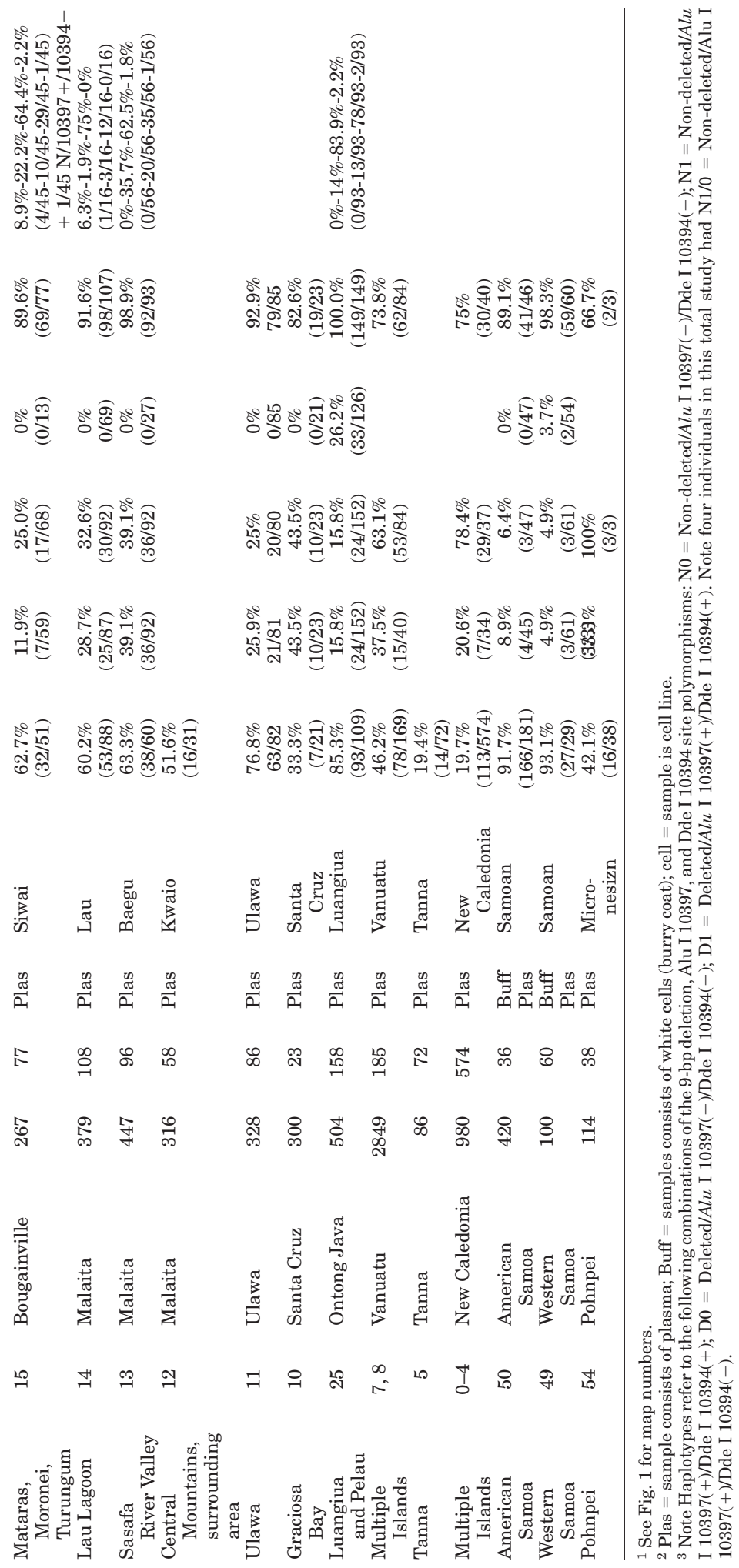




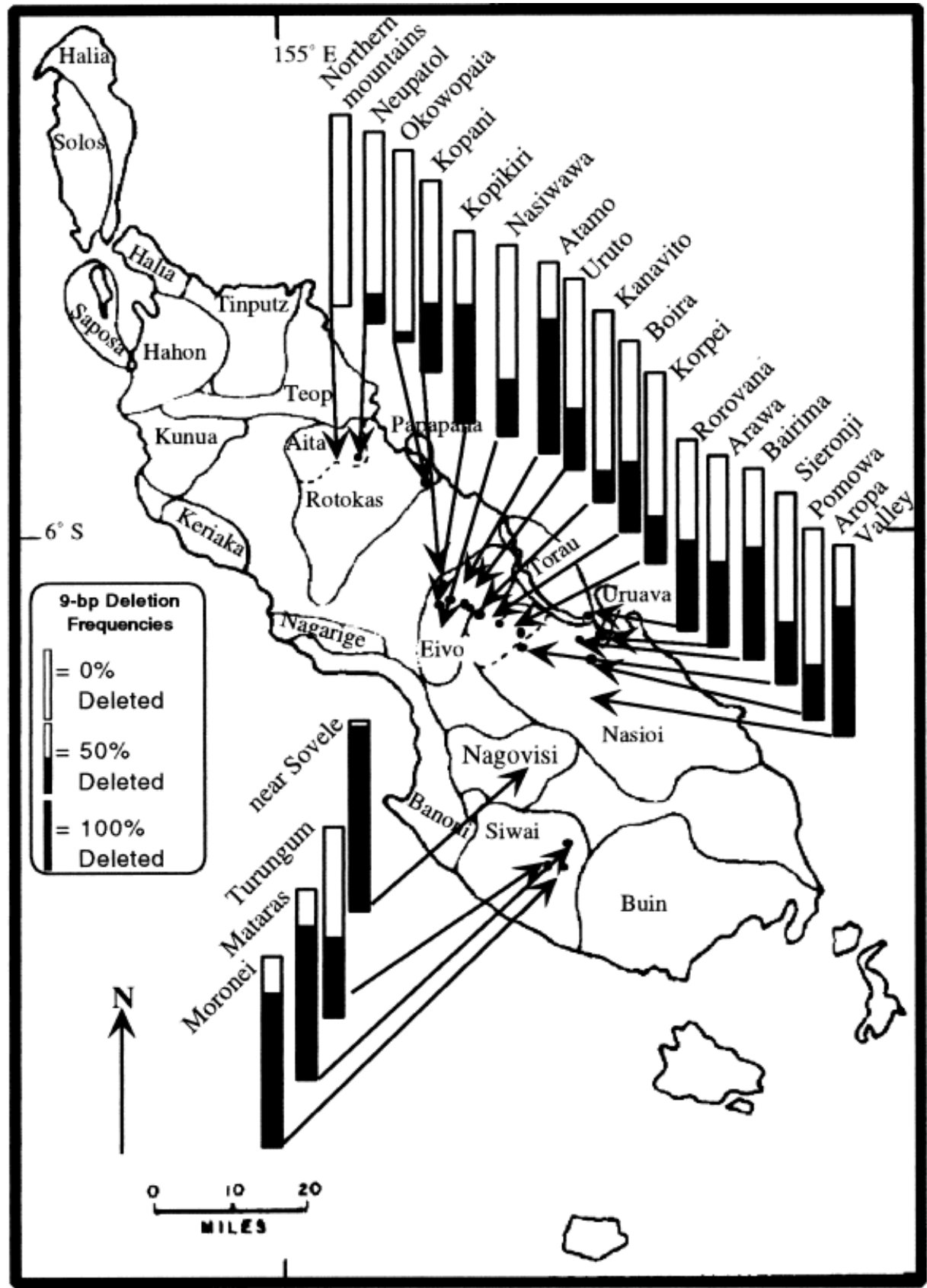

Fig. 2. Village mtDNA RFLP frequencies on Bougainville. Names and figures correspond to those in Table 2. The percentage of the hollow bars filled with black represents the frequency of the 9-bp deletion in that population.

any human language (Wurm, 1975). Recent volcanic activity depopulated a considerable portion of the area, which was only partially resettled by the turn of the century (cf.
Spriggs, 1997, p. 172). The southeastern non-Austronesian speakers (Nasioi, Nagovisi, and Siwai) have a history of extensive trade and marital exchange with Austrone- 
Green Island

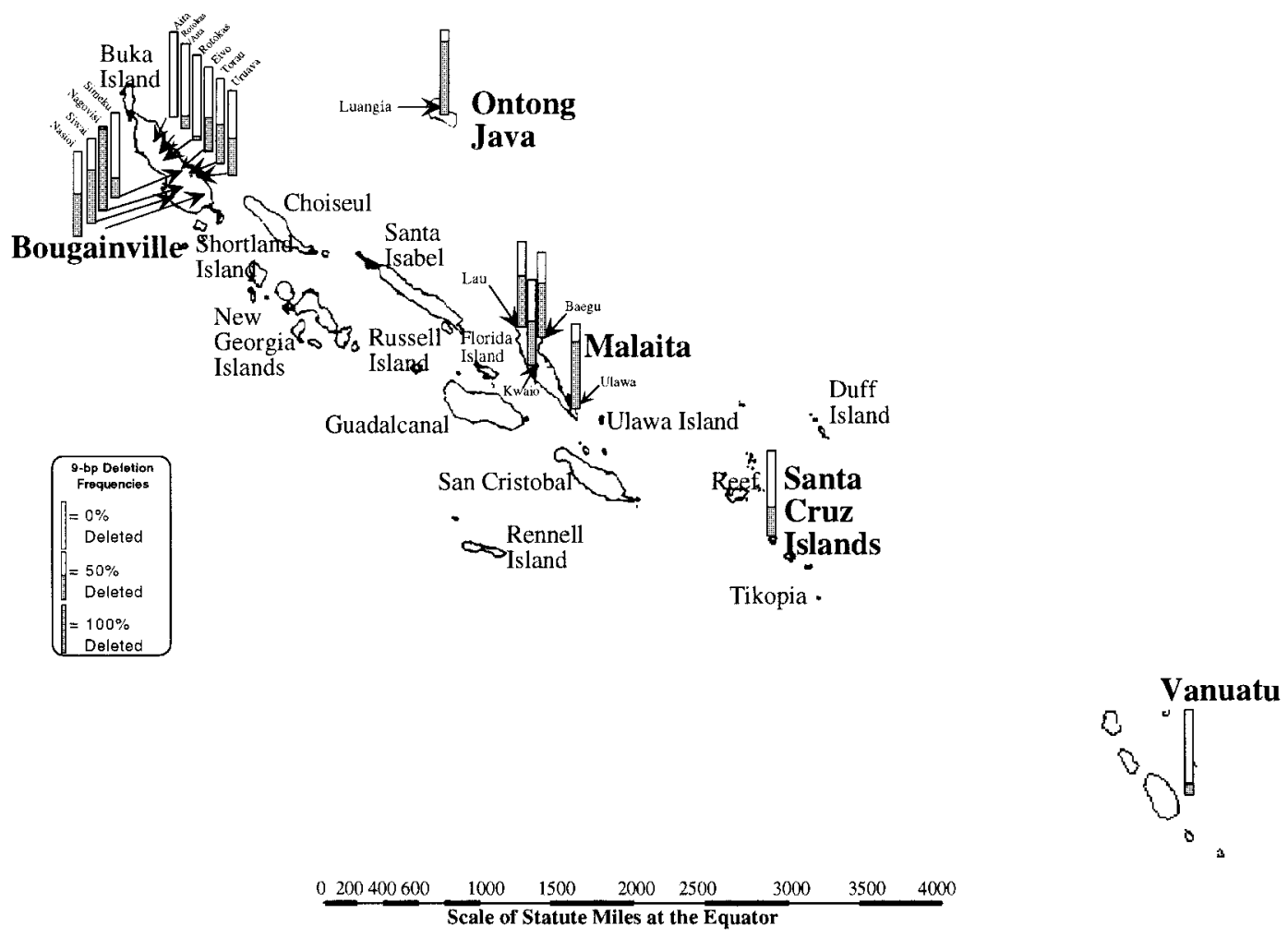

Fig. 3. mtDNA deletion frequencies in Island Melanesia language groups. Names and figures correspond to those in Table 3. The percentage of the hollow bars filled with black represents the frequency of the 9-bp deletion in that population.

sian populations to the south. There are suggestions of considerable recent population movements within the northern part of the island, as well, which would have affected the Eivo at the least. The two Austronesian-speaking groups (belonging to the Meso-Melanesian branch) have even closer and recent ties to southern offshore Austronesians. The Torau-speaking Rorovana moved to their current locale about a century ago from the Shortland Islands, and the Uruava also have ties to the south, but have intermarried extensively with the Rorovana and neighboring non-Austronesian Nasioi (Friedlaender, 1975). At the time of the collection survey in 1966-1967, very few speakers of Uruava remained, an apparently uncommon instance of a non-Austronesian language being adopted by a formerly Austronesian speaking group.
3. Malaita and Ulawa. All three Malaita groups as well as the nearby Ulawans speak very closely related languages (belonging to the Southeast Solomonic Group within Oceanic). While there are no contemporary nonAustronesian groups there, settlement dates for this area can be inferred to extend considerably before the initial Lapita/Proto-Oceanic settlement. Also, traditional trading relationships extending to South Bougainville continued until very recently. The Lau and Baegu populations are geographically and linguistically very close, but live in very different ecological settings. The Kwaio may reflect fewer recent intrusive influences (cf. Mitchell et. al., 1987). The samples were collected in 1986 (Friedlaender, 1990).

4. Santa Cruz. The Santa Cruz (Graciosa Bay area) samples are from a non-Austrone- 
sian speaking group, the only one in Remote Oceania. They represent a relatively recent movement into this area (Green, 1997) and are surrounded by Oceanic speakers (Davenport, 1962; Mazzur et al., 1973a, 1973b, Green, 1997). They are presumed to be a heavily intermixed population. The plasma samples were collected by Mazzur as part of an epidemiological survey of hepatitis transmission and housed in B.S. Blumberg's collection.

5. Vanuatu. These materials come from three islands, primarily from Malo, just south of Santo, but including some people from Malekula and a very few from Ambrym. The languages of these islands belong to the North/Central Vanuatu grouping within Oceanic. The samples were collected in 1976-1977 (Dickie, 1979) and were also housed in Blumberg's collection.

6. Tanna. The languages of Tanna, Erromanga, and Aneityum are recognized as another separate subgroup of Oceanic (South Vanuatu), and because of this distinction we include this small opportunistic Tanna hospital sample from Blumberg's collection.

7. New Caledonia. These materials from Blumberg's collection are a sampling of hospital admissions in Noumea, Yate, and nearby areas. The New Caledonian languages are, according to Pawley and Ross, another subgrouping of Oceanic (sometimes called Southern Oceanic), although closely linked to the South Vanuatu (Tanna etc.) and North/Central Vanuatu subgroups.

8. Ontong Java (Luangiua). This "Polynesian Outlier" has linguistic ties to Western Polynesia and therefore represents the Central Pacific subgrouping of Oceanic in our survey sample. The Luangiua population presumably has experienced a heavy genetic influence from that source. There is also a tradition of some recent contact with Malaita and other "Melanesian" islands, as well as suggestions of interrelations with Micronesia (Mitchell et al., 1987, p.51). The samples were collected in 1986 (Friedlaender, 1990).

9. Pohnpei. These samples from Blumberg's collection represent a last division of Oceanic-Nuclear Micronesian. Rather few samples from this region have been tested for the mtDNA 9-bp deletion, and Pohnpei is one of the Micronesian islands closest to Island Melanesia.

\section{Laboratory methods}

The methods utilized in the analysis of these samples have been routinely and extensively utilized in D.A.M.'s laboratory (Merriwether et al., 1992, 1994, 1996). While most of the plasmas used in this study were collected in the late 1960s and early 1970s, we were successful in extracting and amplifying mtDNA from over $99 \%$ of those attempted. The DNA from buffy coats was amplifiable for $100 \%$ of the mtDNA markers attempted. Because many of the samples were from particularly interesting populations unlikely to be resampled in the near future, and because many are more than 25 years old, we only typed these samples for a small number of mtDNA markers. We concentrated on mtDNA because its high copy number made it more easily recoverable from these old and extremely valuable samples than nuclear markers. The fragmentary nature of the old plasma-derived-DNA, typically $<300 \mathrm{nt}$ in length, required us to screen for known polymorphisms using primer sets that very closely flanked either side of the restriction fragment length polymorphism (RFLP) or in/del site. D-loop sequencing is currently under way in our laboratory, but it is requiring the amplification of many small overlapping polymerase chain reaction (PCR) fragments to achieve the 300-700 nt of sequence typically screened in this kind of study.

\section{DNA extraction from plasma (modifi-} cation of Boom et al., 1990). Up to $450 \mu \mathrm{l}$ plasma, $900 \mu \mathrm{l}$ lysis buffer L6 (168 g Guandise Isothiocyarete [GuSCN] in $100 \mu \mathrm{l}$ Tris $\mathrm{HCl}(\mathrm{pH} 6.4), 22 \mu \mathrm{l} 0.28 \mathrm{M}$ EDTA ( $\mathrm{pH} 8.0$ ), and $3.64 \mathrm{~g}$ Triton X-100, and $\mathrm{dH}_{2} \mathrm{O}$ to $1 \mathrm{~L}$ ), and $40 \mu \mathrm{l}$ silica particles were added to each $1.5 \mathrm{ml}$ microfuge tube and homogenized by vortexing. Following incubation for 10 min at room temperature, the sample was vortexed again for $5 \mathrm{sec}$, centrifuged for 15 sec at $12,000 \times \mathrm{g}$, and the supernatant was decanted. The pellet was washed twice in washing buffer L2 (168 g GuSCN in $100 \mu \mathrm{l}$ 
Tris $\mathrm{HCl}\left(\mathrm{pH}\right.$ 6.4) and $\mathrm{dH}_{2} \mathrm{O}$ to $1 \mathrm{~L}$ ), washed twice with $70 \%$ ethanol, and washed once with acetone. The acetone was decanted and the sample was dried at $56^{\circ} \mathrm{C}$ for $10 \mathrm{~min}$. The pellet was then extracted twice with 100 $\mu l$ elution buffer $(22 \mu \mathrm{l}$ Tris $\mathrm{HCl}(\mathrm{pH} 8.0)$, $0.28 \mathrm{M}$ EDTA ( $\mathrm{pH} 8.0)$ ) by vortexing the pellet and TE and incubating for $10 \mathrm{~min}$ at $56^{\circ} \mathrm{C}$, followed by a 2 min centrifugation at $12,000 \times \mathrm{g}$. The supernatant was transferred to fresh tubes after each elution, centrifuged for $2 \mathrm{~min}$, and used directly as a template for PCR.

2. Amplification and digestion. All samples were amplified by the PCR (Saiki et al., 1988), using the primer sets encompassing the following regions: nucleotides 8195 8317 (8195-For: 5' ATG CTA AGT ATG CTT TAC AG 3; 8317-Rev: 5' ACA GTT TCA TGC CCA TCG TC 3') ; 10284-0489 (10284-For: 5 'CCA TGA GCC CTA CAAACAACT AAC C 3'; 10489-Rev: 5' GTA AAT GAG GGG CAT TTG GTA AAT AT 3'); 16201-16547 (16201For: 5' CAA GCA AGT ACA GCA ATC AAC CCT C 3' 16547-rev: 5' GGAACG TGT GGG CTA TTT AGG $3^{\prime}$ ) ; and 16453-00048 (16453For: 5' CCG GGC CCA TAA CAC TTG GG 3'; 00048-Rev: 5' GCA TGG AGA GCT CCC GTG AGT GG $3^{\prime}$ ). All primers were 20 mer to 28 mer oligonucleotides that precisely match the published sequence (Anderson et al. 1981). DNA amplification was carried out on Perkin Elmer 9600 thermocyclers, without mineral oil. Cycling parameters on the 9600 typically consisted of a $30 \mu \mathrm{l}$ reaction running for 40 cycles of $94^{\circ} \mathrm{C}$ for $0.5 \mathrm{~min}, 55^{\circ} \mathrm{C}$ for $0.25 \mathrm{~min}$, and $72^{\circ} \mathrm{C}$ for $0.25 \mathrm{~min}$, followed by a $48^{\circ} \mathrm{C}$ hold. RFLP typing was performed by digesting of $10 \mathrm{ml}$ of PCR amplified DNA in a cocktail of $1 \mathrm{ml}$ bovine serum albumin (BSA) $(50 \mathrm{mg} / \mathrm{ml}), 2 \mathrm{ml}$ manufacturers $10 \times$ enzyme buffer, 5 units of restriction enzyme, and $\mathrm{dH}_{2} \mathrm{O}$ (to $10 \mathrm{ml}$ total volume). The digest was incubated at $37^{\circ} \mathrm{C}$ overnight, electrophoresed on a $2 \%$ agarose gel, and visualized by ethidium bromide (EtBr) staining.

\section{RESULTS}

The results of the restriction fragment length analyses of the samples are presented in Tables 2 and 3 and Figures 2 and 3 . We have avoided representing the results in either population dendrograms or haplotype trees. In the first place, population-based genetic distance trees take the average distance between all individuals in each pair of populations. Population-based distance trees assume an absence of gene flow, which we know is violated in this situation. Secondly, they require input from many loci for representing summary population relationships. Regarding haplotype trees, as these RFLP results basically resolve themselves into two haplotypes, a frequency distribution of one haplotype is the representation of choice. We did generate a neighbor joining tree of the haplotypes grouped by language group, using Nei's Genetic distance estimate with PHYLIP 3.5 GENDIST and NEIGHBOR programs. Since this tree was effectively based on just three completely linked sites, we do not present it here, but is available upon request from D.A.M. Clustering corresponded to the frequencies of the 9-bp deletion.

The 9-bp deletion. The mtDNA 9-bp deletion frequency ranges in this area from 0.0 to almost 1.0, yet another example of extreme variability in Near Oceania. While this suggests considerable genetic drift and founder effects, there are some important distinctions relating to language.

The populations in this series that lack or have very low frequencies of the 9-bp deletion are those non-Austronesian speakers most removed from the shore and Austronesian influence. Besides the already published results from populations in Highland New Guinea and Australia, this includes our New Britain (Baining) and mountainous North Bougainville (Aita/Rotokas) samples.

All Oceanic-speaking (Austronesian) groups sampled here and throughout the Pacific have high frequencies of the 9-bp mtDNA deletion: the Central Pacific Polynesian speakers, the Nuclear Micronesian speakers, and those speaking languages of the various "Melanesian" subdivisions of Oceanic in Near Oceania. There are some variations in the deletion frequency within particular island groups, most notably in Vanuatu, but these are hardly unexpected, given the small sizes of the populations and the samples. Indeed, our Vanuatu samples 


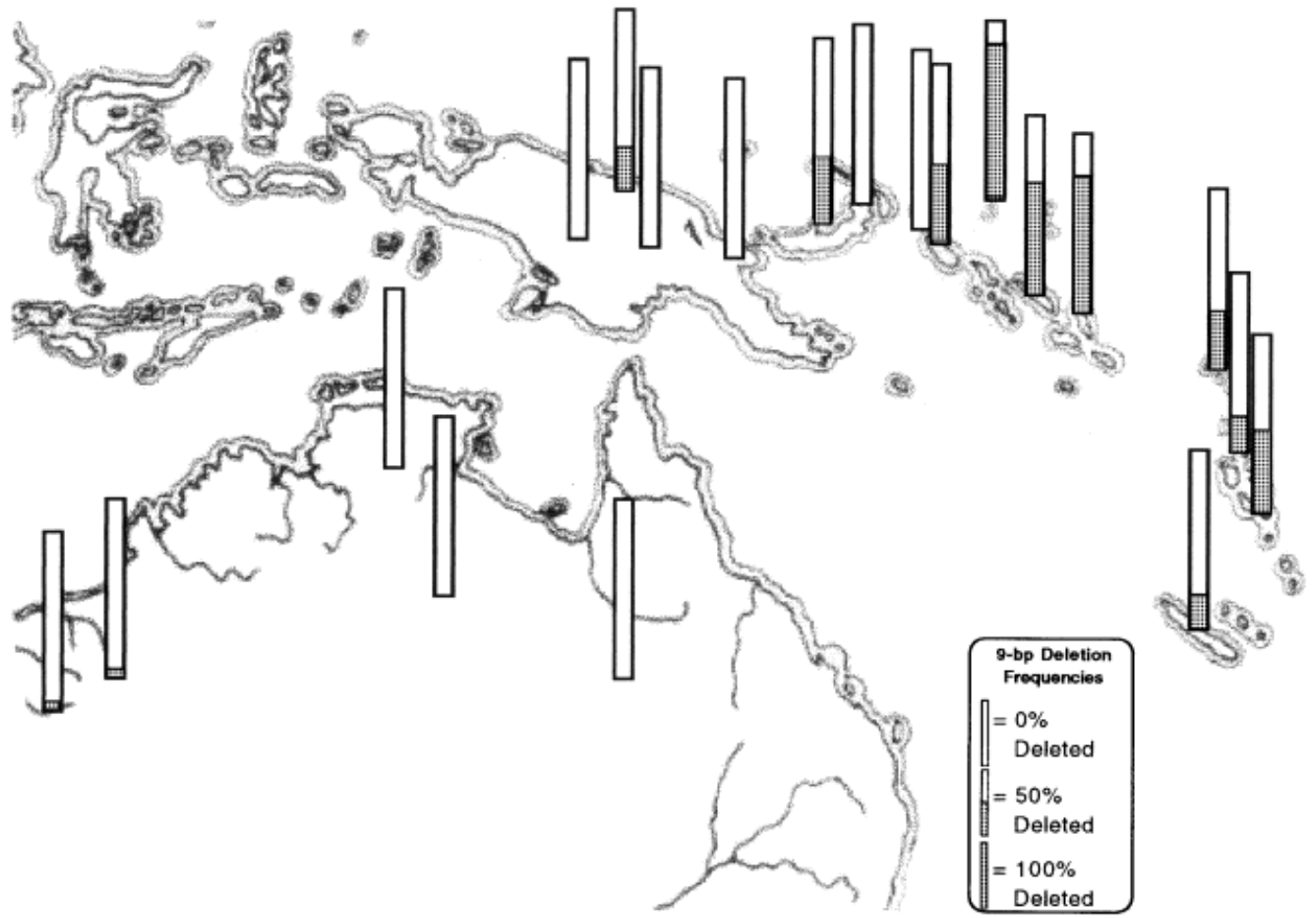

Fig. 4. mtDNA deletion frequencies in Australia, New Guinea, New Britain, and surrounding areas. Names and figures correspond to Tables 1,2, and 3. The percentage of the hollow bars filled with black represents the frequency of the 9 -bp deletion in that population.

have a relatively high (46\%) frequency of the deletion (out of 169 unrelated samples), whereas Lum and Cann (1998) found it at only $12 \%$ in the 25 individuals they studied, and Sykes et al. (1995) found it in $40 \%$ of 56 individuals.

There are exceptions to this languagerelated dichotomy. The east Bougainville groups, Austronesian and non-Austronesian alike have high deletion frequencies. As noted, they have a tradition of exchange and intermarriage among themselves and with Austronesian-speaking groups to the south (Oliver, 1989). The non-Austronesian-speaking Santa Cruz groups also have the deletion, but it is relatively low for that area of the Pacific (Remote Oceania). This situation is compatible with the archaeological and linguistic evidence for the region (Green, 1997) that the movement of these populations into this region by non-Austronesian speakers was recent, and that there was extensive contact with Austronesian-speaking populations during at least two periods. Under such circumstances, one would expect to see low frequencies of the 9-bp deletion. The intensive sampling in Bougainville also reveals considerable variation within language groups, consistent with extensive local founder effects and genetic drift.

Alu I (10397). The distribution of Alu 1 (10397) site gains is almost entirely complementary to that of the 9-bp deletion, with highest frequencies in north Bougainville and in the non-Austronesian Baining of New Britain. Any differences can be attributed to analytic difficulties. The 9-bp deletion haplotypes are universally associated with the Alu I 10397 site loss in Asian populations (Ballinger et al., 1992).

Hae III (16517). This site gain/loss distribution closely parallels that of the 9-bp 
deletion. The only low frequencies are in north Bougainville and north Nasioi (Bougainville), and are elsewhere near fixation. The association between the Hae III 16517 site gain and the region $\mathrm{V}$ 9-bp deletion is consistent with the "Asian" version of this deletion, which is known to have arisen separately in Africa (Merriwether et al., 1992, 1994; Soodyall et al. 1996; Chen et al., 1995) and elsewhere on different mtDNA haplotype backgrounds.

Hae III (16398). This site gain is entirely absent except among the Samoans (0.02) and the related Ontong Java population, where it reaches the frequency of 0.26 . This suggests just how marked the founder effect can be in one single instance in this region.

Haplotypes. We do not have complete sets of all five RFLPs on every sample, due to their irregular quality. For the samples successfully typed for multiple markers, the 9-bp deletion is nearly universally associated with the loss of the $A l u$ I 10397 and Dde I 10394 (typical for the Asian-derived 9-bp deletion haplotypes). There were two other haplotype combinations found at higher frequencies: non-deleted individuals possessing the Alu I 10397 and Dde I 10394 site gains, and non-deleted individuals with the Alu I 10397 and Dde I 10394 site losses. Table 2 summarizes the haplotype frequencies for populations typed in this study. The primary haplotypes are:

N0 $=($ Non-Deleted/Alu I 10397(-)/Dde I 10394(-)

$\mathrm{N} 1=($ Non-Deleted/Alu I 10397(+)/Dde I 10394(+)

$\mathrm{D} 0=($ Deleted/Alu I $10397(-) /$ Dde I 10394(-)

$\mathrm{D} 1=($ Deleted/Alu I 10397(+)/Dde I 10394(+)

In two Bougainville non-Austronesian populations, the Eivo and the Siwai, a fifth combination was seen in three and one individuals, respectively:

N1/0 (Non-Deleted/Alu I 10397(+)/Dde I 10394(-)

Control region variants. The Polynesian Motif sites: Table 4 shows the relationship between the 9-bp deletion and the Polynesian motif sites (16189, 16217, 16247, and 16261) in a subset of the samples in this study. Table 4 shows the frequencies of each polymorphism, plus five haplotype combinations of these four polymorphisms, in the Nasioi and Nagovisi of Bougainville, and the Luangiua of Ontong Java. The haplotype numbers in Table 4 represent transitions in nucleotide positions. Position 16189, T to C, $16217 \mathrm{~T}$ to $\mathrm{C}, 16261 \mathrm{C}$ to T, and $16247 \mathrm{~A}$ to $\mathrm{G}$. The numbers refer to the following combinations: (1) TTCA, (2) CTCA, (3) CCCA, (4) CCTA, (5) CCTG, and Other CCCG. The mutations are represented in phylogenetic order as presented by Lum et al. (1994).

\section{DISCUSSION}

This remarkably simple pattern of the mtDNA 9 base pair deletion frequency across the complex populations of Near and Remote Oceania holds some very clear implications and answers to questions posed in the Introduction.

\section{Are there any Austronesian-speaking populations that lack the mtDNA haplotype marker?}

Without exception, all Oceanic-speaking populations surveyed to date, and Austronesian speakers more generally, have the mtDNA 9-bp deletion marker.

\section{Is there anything left of the presumed proto-Polynesian "bundle" of genes, language and culture that apparently arrived in Island Melanesia about 3,500 years ago?}

This reinforces earlier work that emphasized the genetic similarities of Austronesian-speaking populations in Near Oceania and elsewhere (cf. Giles et al., 1965; Schanfield, 1977; Friedlaender, 1987), in spite of sometimes strong resemblances to immediately neighboring groups (cf. Serjeantson and Gao, 1995). This pattern is consistent with the hypothesis that "the Lapita People," speaking Proto-Oceanic, arrived in Island Melanesia without having experienced extensive intermixture, still retaining distinctive genetic ties to Southeast Asian populations. 


\section{Is this deletion haplotype Asiatic in origin, and when was it introduced?}

This was a recent and rapid event. Mismatch analyses of mtDNA control region sequence data from our lab from Santa Cruz Islanders shows that their 9-bp deleted haplotypes in the control region are indistinguishable in age from Polynesian ones. The distribution of mismatches in both the Santa Cruz and Polynesian 9-bp deleted lineages was centered around 1.5. The 9-bp deleted lineages we have sampled from New Guinea are also identical in their distribution (Merriwether et al, in press). In contrast, the Southeast Asian control region haplotypes for 9-bp deleted individuals are older than those found in the Pacific (Redd et al., 1995), indicating the deletion arose there, rather than indigenously in Near Oceania.

All of the samples sequenced thus far for the D-loop are identical with variants of the Polynesian motif (different combinations of $16189, \mathrm{~T}$ to $\mathrm{C}, 16217 \mathrm{~T}$ to $\mathrm{C}, 16261 \mathrm{C}$ to $\mathrm{T}$, and 16247 A to G), as shown in Table 4 . These samples are from Nasioi, Nagovisi, and Ontong Java.

None of the 9-bp deleted individuals were haplotype 1 , which is the non-Polynesian motif pattern in Table 4 . All were haplotypes 2-5 or "other." Haplotypes 2-5 were reported by Lum et al. (1994) and Redd et al. (1995). The haplotype we called "other" is the pattern CCCG for positions 16189, 16217, 16261 , and 16247 , respectively. The Melanesians and Polynesians appear to have the same Polynesian Motif sites, indicating a common origin. We take this to indicate a single Asian origin for the 9-bp deletion in the vast majority of our samples.

However, we did identify a dozen deleted individuals (2.1\% of 580 individuals) whose RFLP haplotypes did not share the common Asian-deletion background (called D1 in Table 3). These were found widely distributed in very low frequency in our samples, and do not appreciably affect the frequency estimates for the deletion in these populations.

The common Asian version of the deletion normally occurs on a DO background (i.e., lacking the Alu I 10397 and Dde I 10394 site gains). The D1 deletion haplotype could 
have arisen in a single event if the deletion arose on the N1 background. The Alu I 10397 and Dde I 10394 mutations can be lost by a single mutation, since their recognition sites overlap, so it would only take a single mutation to change from N0 to N1, D0 to D1, N0 to D0, or N1 to D1. Considerably higher resolution data will be required to resolve whether or not there is more than one origin for the deletion in our sample.

\section{Are there non-Austronesian-speaking populations that lack the 9-bp deletion, 3,500 years after its introduction to the Island Melanesia region?}

The more remote or inland non-Austronesian-speaking groups in Near Oceania lack the mtDNA 9-bp deletion. For those descendant Oceanic-speaking populations that remained in Near Oceania, there has been sufficient time for intermarriage, shortrange migrations, and population expansions to obliterate the initial contrast in the presence versus absence of the deletion in most, but not all, instances. Some Oceanicspeaking groups have rather low frequencies of the deletion, suggesting extensive intermarriage, and some non-Austronesianspeaking groups (especially in southeast Bougainville) have high deletion frequencies. Yet the Baining of New Britain and Aita/Rotokas of northwest Bougainville still have no detectable frequencies of the marker.

The mismatch distributions of the non9-bp deleted control region haplotypes from the Garaina, Popondetta, and Bundi areas of New Guinea, along with those from Santa Cruz, are much deeper and much more diverse than the deleted clusters in those populations, implying greater age (Merriwether et al., in press). For example, the mismatch distributions of the non-9-bp deleted lineages for Santa Cruz center around seven differences (Merriwether, 1998). This creates a bimodal distribution when the deleted lineages are included. This supports the idea of a relatively recent Austronesian-speaking intrusion into existing non-Austronesian populations.

What is the cause of the extreme genetic variation within Bougainville populations?

A satisfactory explanation for the pattern of biological heterogeneity on Bougainville is now clear. It reflects the contrast between (at least) two distinctive populations: the earlier non-Austronesian populations and the recently arrived Austronesians. As noted, the biological heterogeneity within Bougainville, particularly between northwest Bougainville non-Austronesian mountaineers, on the one hand, and southeast non-Austronesian and Austronesian speakers, on the other, is remarkable. In many instances, it is greater than that reported among New Guineans and always greater than among all Polynesians [cf. Friedlaender (1975, 1987) for a review of data on dermatoglyphics, odontometrics, anthropometrics, as well as a number of single gene variants].

Terrell and Fagan (1975) had argued that local adaptations to different ecological zones within Bougainville were likely responsible for the sharp distinctions within the island. Rogers and Harpending (1983) suggested that the pattern of blood genetic variability was within the expectations of random drift from a single population source, but that the anthropometric variability was not, implying other causes were responsible (they favored some sort of differential selection). Sokal and Friedlaender (1982) had suggested a number of migrations were responsible. We had argued these were clearly very ancient distinctions, certainly on the order of 10,000 years or more (Friedlaender, 1987, p. 354-55), certainly predating the appearance of Austronesians, and possibly going back to initial settlement (now known to have been at least 29,000 years ago).

The new mtDNA results show that many of the biological/genetic distinctions of the northwest Bougainville mountaineers are not the result of recent diversification in place, and are very unlikely to be the result of differential selection. These distinctions include very high Inv $(\mathrm{Km})^{1,2}$ frequencies (Rhoads and Friedlaender 1987), high Gm ${ }^{\text {za;g }}$ frequencies (Steinberg and Cook, 1982), and a distinctive Apo A 4 deletion (Kamboh et al., 1994). They are almost certainly remnants of pre-Austronesian Bougainville populations, whose distinctiveness has been diluted in other areas of the island. 


\section{Do the non-Austronesian populations in New Guinea and Island Melanesia have an identifiable genetic unity?}

Possible residual genetic ties among the non-Austronesian-speaking populations in Island Melanesia remain to be identified. The mtDNA results, focusing on the deletion marker tied to Austronesians, indicate nothing about possible affinities among the other populations in the region. What is surprising, perhaps, is the high frequency the 9-bp deletion has attained in so many nonAustronesian populations in Near and Remote Oceania since its recent introduction. This indicates extensive admixture between the Austronesian and non-Austronesian populations. The deletion almost reaches fixation in a few non-Austronesian populations (e.g., the Nagovisi of Bougainville, with a frequency of 0.98 ).

There are some long-standing suggestions, particularly from the distribution of Gm haplotypes, of substantial genetic differences among non-Austronesian groups in New Britain, northwest Bougainville, and New Guinea (Curtain et al., 1971; 1972) that may (or may not) be attributable to differential Austronesian influence. We also take the extraordinary pattern of viral heterogeneity in the Solomons and Vanuatu as an important indicator of long-term isolation (Mazzur et al., 1973a, 1973b; Dickie, 1979, Yanagihara, 1994) coupled with a relatively recent Austronesian introduction of Asian/cosmopolitan variants.

\section{GENERAL CONCLUSIONS}

It is important to underline the great extent of the genetic heterogeneity of populations in the Southwest Pacific, even disregarding the Austronesian-speaking groups entirely. Its magnitude is second only to that of Africa (Cavalli-Sforza et al., 1994; Horai and Hayasaka, 1990), with implications for the antiquity of modern Homo sapiens. When they have been included in worldwide gene tree comparisons, small Bougainville samples are often more distant from New Guinea Highlanders than are Australian Aborigines, although this is not often noted (e.g., Bowcock et al., 1994). Likewise, Kidd and Kidd (1996) have found a number of private polymorphisms among 24 samples from the Aropa Valley Nasioi (included in Group 17), even though our current study shows the Nasioi have experienced heavy gene flow from Austronesians.

In his overview of polymorphic variation in Papua New Guinea and Australia, Kirk (1992) identified only three distinctive populations, based on unique allele occurrences, that he called Australoid, Proto-Papuan (basically non-Austronesian), and Austronesian. We suggest that the polymorphisms he had information on were inadequately covered for non-Austronesian-speaking groups in Island Melanesia, so that he has very likely underestimated diversity there. This has been a frequent problem in population diversity studies in the region.

\section{Can the contemporary array of languages, here or elsewhere, reveal anything about the pattern of biological affinities?}

Patterns of language and genetic variation are often interrelated and can provide special insights on current and past population relationships. In Papua New Guinea, a number of genetic studies have shown apparently contradictory associations of language and genetic affinities. While Giles et al. (1965) described a very clear genetic distinction between nearby Austronesian and nonAustronesian language groups in the Markam Valley, Serjeantson could find no such relationship in the Madang region [cf. Serjeantson et al. (1992) and Kirk (1992) for an overview]. As noted, Friedlaender's (1975) work on Bougainville showed a strong linguistic effect on biological affinities, but could not replicate the same Austronesian/ nonAustronesian distinction in $\mathrm{Gm}$ allotypes found in the Markham.

Because of these sorts of discrepancies in inferring past relationships from current patterns, Terrell and Fagan (1975) argued that geographic proximity and ecology are going to be the best determinants of contemporary relationships for archaeological and biological characteristics alike, an essentially anhistoric, equilibrationist position. They called this a geographical systems approach (1975). However, it proved to be both insufficient and misleading in explain- 
ing the specifics of the Bougainville pattern of variation, as well as the correlates of the Austronesian dispersal more generally (Friedlaender, 1987). Undeterred, Terrell, and Welsch undertook a related study of material culture variation along the New Guinea north coast. They concluded there was no significant association between distributions of language and early $20^{\text {th }}$ century cultural assemblages among a large number of Austronesian and non-Austronesian villages, once the effect of geographic propinquity had been accounted for. They argued by analogy that similarities of artifact inventories at Lapita sites were irrelevant to notions the people involved might be a single linguistic population or ethnic group (Terrell, 1989; Terrell and Welsch, 1990; Welsch et al., 1992). However, in a reanalysis of Terrell and Welsch's published data, Romney, Moore, and Roberts (Moore and Romney, 1994, 1996; Roberts et al., 1995) came to a very different conclusion. They found a remarkable clustering of material culture distributions along Austronesian/non-Austronesian lines, showing a major association between language and material culture distributions at least as powerful as geographic propinquity. As a first step in their analysis, Terrell and Welsch had reduced their artifact frequency data for each village to presence/absence distributions. Then, they calculated pair-wise distance statistics for village samples in the different data sets (linguistic, geographic, and material culture distinctions). Finally, they carried out bivariate regression analyses between the sets of (nonindependent) pair-wise distances. In doing these transformations, they lost information contained in the original data set, thereby losing considerable power in their analyses. By contrast, Moore and Romney's reanalysis achieved strengths of association six times those reported by Welsch and Terrell by retaining the original frequency profiles and using simple rank order (scaling) comparisons as the basis of their correlation tests.

We do not maintain that language boundaries per se are particularly effective or long-lasting barriers to intermarriage. To the contrary, a number of studies, including one of ours from Bougainville, have indi- cated that migration rates across language boundaries are usually high enough to obliterate any prior genetic distinctions, given a reasonable number of generations (Friedlaender, 1975; Ward , 1996; Long et al., 1986; and Boyce et al., 1978); and, as noted, families and whole villages do adopt new languages on occasion. However, contemporary language relationships often act as summary indicators for population movements over the past few hundreds or even thousands of years, before subsequent gene flow and language borrowing have a chance to erase the pattern [see Friedlaender (1987, pp. 357-367) and Barbujani and Sokal (1990) for discussion]. Friedlaender (1975) showed they could on occasion be considerably more informative than contemporary patterns of migration or geographic propinquity.

We believe there are two keys to understanding the inconsistencies of the New Guinea and Island Melanesia distributions of the mtDNA, Gm, and thalassemia alleles. First, the nature of non-Austronesian/Austronesian contact in the separate regions has almost certainly been different. The Markham Austronesian contact may have been minimal and recent (cf. Kirk, 1992, p.180-181), while contact in the Madang region has been more fluid. The Bougainville situation has an added dimension. Pawley and Ross (1996) suggest the Austronesians coming to Bougainville from New Britain were already heavily "Papuanized," which has clear implications for the Gm allele distribution distinctions there.

Second, maternally transmitted markers may well have spread to the hinterlands of Near Oceania more slowly than paternally transmitted ones. A number of anecdotes make this a likely explanation. Young women from beach villages were supposed to resist marriages inland; the life of a bush woman was known to be especially strenuous. If this has an important effect, it could explain why the Gm and Apo A allelic distributions are somewhat less distinctive than the mtDNA pattern in Bougainville. In this regard, it is similar to the distinction between mitochondrial and nuclear markers found in Micronesia and Polynesia by Lum et al. (1998). 


\section{Can molecular genetics contribute to} studies of population history?

Molecular genetic and historical linguistic comparisons can be far more decisive in the reconstruction of population histories than archaeology alone. Green and Kirch have been arguing that "the triangulation approach" of archaeology, lexical reconstruction, and comparative ethnography can provide a richer understanding of the past than does any one of the three by itself, although they privilege archaeology as the starting point for the reconstruction of Lapita (cf. Green, 1986). We entirely agree with this synthetic view. Of course, only archaeology can provide absolute dates for specific events in human prehistory, and archaeology is certainly the primary source of information on past cultural and social conditions and their transformations (although lexical reconstructions can be remarkably informative). However, the incomplete nature of the archaeological record leaves it open to constant revision and reinterpretation. We emphasize the growing power of contemporary molecular genetics in reconstructing past population movements and interactions, especially over the last $10,000-20,000$ years. It will continue to provide new insights into past population relationships in the Pacific and elsewhere (see, for example, Sykes et al., 1996; van Holst Pellekaan et al. 1998; Lum et al. 1998; Melton et al. 1998; Forster et al. 1998; Macaulay et al., 1999; Goldstein et al., 1999; Stephens et al. 1998; Karafet et al. 1999; Lee et al. 1999; Malaspina et al. 1998; Reich and Goldstein 1998; Torroni et al. 1998; Kittles et al. 1999; Bertranpetit et al., 1996; Kaplan et al., 1994; Soodyall et al., 1996; Merriwether et al., 1991; 1996).

In the future, the most productive genetic research strategy on human population histories will focus on the distributions of a small set of informative haplotype variants across large sets of population samples, rather than a large number of allelic markers yielding summary distance measures for a small set of populations. Genetic distance statistics can never reveal much about the causes of population distinctions, and even less about any sequence of events, whether mutations, migrations, or episodes of selection.

The choice of loci for such studies is critical. HLA is an instructive case. At one time, it appeared information from this hypervariable set of loci might be sufficient to provide a powerful description of human population histories, whatever the role of selection had been. Yet misleading similarities in antigenic status often masked important distinctions in genetic and historical derivation (e.g., Gao et al., 1992; Serjeantson and Gao, 1994). DNA sequencing at the HLA loci has made the picture clearer, but the problems of hypervariability and rapid recombination rates make it much less informative than more constant regions of the genome. Similar problems occur with descriptions based on STRs and VNTRs.

We can certainly reject Terrell and Fagan's dismissal of the genetic data from the Pacific. It is now possible to identify the likely place of origin of a specific mutational event, its relative dating, and its subsequent spread to other regions. We are able to establish diffusion patterns of maternally and paternally inherited neutral DNA fragments to compare with allele patterns presumed to be under selective pressure. This approach will continue to reveal a great deal about the nature of past population relations and migrations, as well as selection. We anticipate it will rapidly resolve the divergences in conclusions from mtDNA, allozyme, and alpha globin data sets in the Pacific.

\section{ACKNOWLEDGMENTS}

Baruch Blumberg generously allowed us access to his collection of old plasmas from Santa Cruz and Vanuatu, collected by Elizabeth Dickie and Scott Mazzur. Thanks to James Noll, Evan Lyon, Derek Najarian, and Dan Shraeger for help typing, assembling, and transporting samples, and to William Davenport and Elizabeth Dickie for genealogical and ethnographic information on Santa Cruz and Vanuatu. We are indebted to a number of people who offered comments on earlier drafts of the manuscript, but particularly to Matthew Spriggs and Roger Green for their extensive corrections, suggestions, and patience. 


\section{LITERATURE CITED}

Allen J. 1984. In search of the Lapita homeland. J Pacific Hist19:186-201.

Allen J. 1996. The pre-Austronesian settlement of Island Melanesia. In: Goodenough WH, editor. Prehistoric settlement of the Pacific. Philadelphia: American Philosophical Society. p 11-27.

Anderson S, Bankier AT, Barrel BG, DeBulin MHL, Coulson AR, Drouin J, Eperon IC, Nierlich DP, Roe BA, Sanger F, Schreier PH, Smith AJH, Staden R, Young IG. 1981. Sequence and organization of the human mitochondrial genome. Nature 290:457-465.

Ballinger SW, Schurr TG, Torroni A, Gan YY, Hodge JA, Hassan K, Chen K-H, Wallace DC. 1992. Southeast Asian mitochondrial DNA analysis reveals genetic continuity of ancient Mongoloid migrations. Genetics 130:139-152.

Barbujani G, Sokal RR. 1990. Zones of sharp genetic change in Europe are also linguistic boundaries. Proc Natl Acad Sci USA 87(5):1816-1819.

Bellwood P. 1985. Prehistory of the Indo-Malaysian Archipelago. Sydney: Academic Press.

Bellwood P. 1989. The colonization of the Pacific: some current hypotheses. In: Hill AVS, Serjeantson SW, editors. The Colonization of the Pacific: A genetic trail. Oxford: Oxford University Press. p 1-59.

Bellwood P. 1996. The origins and spread of agriculture in the Indo-Pacific region: Gradualism and diffusion or revolution and colonization? In Harris DR, editor. The origin and spread of agriculture and pastoralism in Eurasia. Washington, D.C.: Smithsonian Institution Press. p 465-498.

Bellwood P, Fox JJ, Tryon D. 1995. The Austronesians in history: Common origins and diverse transformations In: Bellwood P, Fox JJ, Tryon D, editors. The Austronesians: Historical and comparative perspectives. Canberra: Australian National University (Department of Anthropology). p 1-16.

Benedict P. 1975. Austro-Thai language and culture, with a glossary of roots. New Haven: HRAF Press.

Bertranpetit J, Calafell F, Comas D, Perez-Lezaun A, Mateu E. 1996. Mitochondrial DNA sequences in Europe: an insight into population history. In Boyce AJ, Mascie-Taylor CGN, editors. Society for the Study of Human Biology Symposium 38: Molecular biology and human diversity. Cambridge: Cambridge University Press. p 112-129

Betty DA, Chin-Atkins AN, Croft L, Sraml M, Easteal S. 1996. Multiple independent origins of the COII/ tRNA $^{\text {Lys }}$ intergenic 9-bp mtDNA deletion in aboriginal Australians. Am J Hum Genet 58:428-433.

Boyce JA, Harrison GA, Platt CM, Hornabrook RW Serjeantson S, Kirk RL, Booth PB. 1978. Migration and genetic diversity in an island population: Kar Kar, Papua New Guinea. Proc Roy Soc London. B202: 269-95.

Black FL. 1991. Reasons for the failure of genetic classifications of South Amerind populations. Hum Biol 63:763-74.

Blust R. 1996a. Austronesian culture history: the windows of language. In: Goodenough, editor. Prehistoric settlement of the Pacific. Philadelphia: American Philosophical Society. p 28-37.

Blust R. 1996b. Beyond the Austronesian homeland: the Austric hypothesis. In: Goodenough WH, editor. Prehistoric settlement of the Pacific. Philadelphia: American Philosophical Society. p 117-140.

Bonatto SL, Redd AJ, Salzano FM, Stoneking M. 1996. Lack of ancient Polynesian-Amerindian contact. Am J Hum Genet 59:253-256.

Boom R, Sol CJA, Salimans MMM, Jamsen CL, Dillen
PMEW-V, Noordaa JVD. 1990. Rapid and simple method for purification of nucleic acids. J Clin Microbiol 28:495-503.

Bowcock AM, Ruiz-Linares A, Thofohrde J, Minch E, Kidd JR, Cavalli-Sforza LL. 1994. High resolution of human evolutionary trees with polymorphic microsatellites. Nature 368:455-457.

Cann R, Lum JK. 1996. Mitochondrial myopia: Reply to Bonnato et al. Am J Hum Genet 59:256-258.

Capell A. 1967. A lost tribe in New Ireland. Mankind 6(10):499-509

Cavalli-Sforza LL, Menozzi P, Piazza A. 1994. The history and geography of human genes. Princeton, NJ: Princeton University Press.

Chang K-C, Goodenough WH. 1996. Archaeology of Southeastern China and its bearing on the Austronesian homeland. In: Goodenough WH, editor. Prehistoric settlement of the Pacific. Philadelphia: American Philosophical Society. p 36-56.

Chen Y-S, Torroni A, Excoffier L, Santachiara-Benereecetti AS, Wallace DC. 1995. Analysis of mtDNA variation in African populations reveals the most ancient of all human continent-specific haplogroups. Am J Hum Genet 57:133-149.

Curtain CC, van Loghem E, Baumgarten A, Golab T, Gorman J, Rutgers CF, Kidson C. 1971. The ethnological significance of the gamma-globulin $(\mathrm{Gm})$ factors in Melanesia. Am J Phys Anthropol 34:257-71.

Curtain CC, van Loghem E, Fudenberg HH, TIndale NB, Simmons RT, Doherty RL, Vos G 1972. Distribution of the immunoglobulin markers at the $\mathrm{IgG}_{1}, \mathrm{IgG}_{2}$, $\mathrm{IgG}_{3}, \mathrm{IgA}_{2}$ and $\mathrm{K}$-chain loci in Australian Aborigines: Comparison with New Guinea populations. Am J Hum Genet 24:145-55.

Daniels J, Daniels C. 1993. Sugarcane in prehistory. Archaeol Oceania 28(1):1-7.

Davenport W. 1962. Reply to Arthur Caplet: Oceanic Linguistics Today. Curr Anthropol 3:400-402.

Diamond JM. 1988. Express train to Polynesia. Nature 326:307-308.

Dickie ER. 1979. Family behavior and the transmission of hepatitis B virus in Malo, New Hebrides. Ethology, ethnography and epidemiology in the study of the natural history of disease. University of Pennsylvania, Ph. D. thesis.

Finney B. 1996. Colonizing and island world. In: Goodenough WH, editor. Prehistoric settlement of the Pacific. Philadelphia: American Philosophical Society. p 71-116.

Foley WA. 1986. The Papuan languages of New Guinea. Cambridge: Cambridge University Press.

Forster P, Kayers M, Meyer E, Roewer L, Pfeiffer H, Benkmann H, Brinkmann B. 1998. Phylogenetic resolution of complex mutational features at Y-STR DYS390 in Aboriginal Australians and Papuans. J Molec Biol Evol 15:1108-14.

Friedlaender JS. 1975. Patterns of human variation: The demography, genetics, and phenetics of Bougainville Islanders. Cambridge, MA: Harvard University Press.

Friedlaender JS. 1987. Conclusion. In: Friedlaender JS, editor. The Solomon Islands project: A long-term study of human biology and culture change. Oxford: Oxford Science Publications. p 351-364.

Friedlaender JS. 1990. The Solomon Islands Project: An introduction. Am J Phys Anthropol 81:459-464.

Friedlaender JS, Steinberg AG. 1970. Anthropological significance of gamma globulin ( $\mathrm{Gm}$ and Inv) antigens in Bougainville Island, Melanesia. Nature 228:59-61. Froehlich J W. 1987. Fingerprints as phylogenetic markers in the Solomon Islands. In: Friedlaender JS, editor. The Solomon Islands project: A long terms 
study of human biology and culture change. Oxford: Oxford Science Publications. p 175-214.

Gallipaud JC. 1990. The physico-chemical analysis of ancient pottery from New Caledonia. In: Spriggs MJT, editor. Lapita design, form and composition: Proceedings of the Lapita Design Workshop, Canberra Australia, December 1988. Occasional Papers in Prehistory No. 19.Canberra, Australia: Australia National University. pp 134-142.

Gao X, Brattier K, Trent R, Sergeants S. 1992. HLADR,DQ nucleotide sequence polymorphisms in five Melanesian populations. Tissue Antigens 40:31-37.

Giles E, Organ E, Steinberg AG. 1965. Gamma-globulin factors (Gm and Inv) in New Guinea: anthropological significance. Science 150:1158-1160.

Goldstein DB, Reich DE, Bradman N, Usher S, Seligsohn U, Peretz H. 1999. Age estimates of two common mutations causing factor XI deficiency: recent genetic drift is not necessary for elevated disease incidence among Askenazi Jews. Am J Hum Genet 64:1071-75.

Grocer P, Mbabane M, Campbell J. 1991. Archaeology and geomorphology of the Vanilla Coast, Papua New Guinea: Preliminary results. Archaeol Oceania 26(3): 119-122.

Green RC. 1986. Some basic components of Ancestral Polynesian settlement system: building blocks for more complex Polynesian societies. In: Kirch PV, editor. Island societies. Archaeological approaches to evolution and transformation. London: Cambridge University Press. p 50-54.

Green RC. 1991. Near and Remote Oceania - disestablishing "Melanesia" in culture history. In: Pawley A, editor. Man and a half: Essays in Pacific anthropology and ethnobiology in honour of Ralph Bulmer. Auckland: The Polynesian Society. p 391-501.

Green RC. 1997. Linguistic, biological, and cultural origins of the initial inhabitants of Remote Oceania. N Zeal J Archaeol 17:5-27.

Hagelberg E, Clegg JB. 1993. Genetic polymorphisms in prehistoric Pacific Islanders determined by analysis of ancient bone DNA. Proc Roy Soc Lond Ser B 252: 163-70.

Hagelberg E, Qevedo S, Turbon D, Clegg JB. 1994. DNA from prehistoric Easter Islanders. Nature 369:25-26.

Harihara S, Momoki H, Suutou Y, Shimizu K, Omoto K. 1992. Frequency of the 9-bp deletion of mitochondrial DNA among Asian populations. Hum Biol 64:161-166.

Hertzberg M, Mickleson KNP, Serjeantson SW, Prior JF, Trent RJ. 1989. An Asian specific 9-bp deletion of mitochondrial DNA is frequently found in Polynesians. Am J Hum Genet 44:504-510.

Hill AVS, O’Shaughnessy DF, Clegg JB. 1989. Haemoglobin and globin gene variants in the Pacific. In: Hill AV, Serjeantson SW, editors. The colonization of the $\mathrm{Pa}$ cific: a genetic trail. Oxford: Clarendon, pp. 246-285.

Horai S, Hayasaka K. 1990. Intraspecific nucleotide sequence differences in the major non coding region of human mitochondrial DNA. Am J Hum Genet 46:828842 .

Horai S, Kondo R, Nakagawa-Hattori Y, Hayasaki S, Sonoda S, Tajima K. 1993. Peopling of the Americas, founded by four major lineages of mitochondrial DNA. Molec Biol Evol 10:23-47.

Houghton P. 1996. People of the Great Ocean: Aspects of human biology of the early Pacific. Cambridge: Cambridge University Press.

Howells WW. 1979. Physical anthropology. In: Jennings JD, editor. The prehistory of Polynesia. Cambridge MA: Harvard University Press. pp 271-85.

Irwin GJ. 1992. The prehistoric exploration and colonization of the Pacific. Cambridge: Cambridge University Press.

Kamboh MI, Friedlaender JS, Ahn YI, Ferrell RE. 1994.
A common deletion polymorphism in the apolipoprotein A4 gene and its significance in lipid metabolism. Arterioscl Thromb 14(5):656-662.

Kaplan NL, Lewis PO, Weir BS. 1994.. Age of the detalF508 cystic fibrosis mutation. Nature Genet 8:216.

Karafet TM, Zegura SL, Posukh O, Osipova L, Bergen A, Long J, Goldman D, Klitz W, Harihara S, de Knijff P, Wiebe V, Griffiths RC, Templeton AR, Hammer MF. 1999. Ancestral Asian source(s) of New World Ychromosome founder haplotypes. Am J Hum Genet 64:817-31.

Kelly KM. 1990. Gm polymorphism, linguistic affinities, and natural selection in Melanesia. Curr Anthropol $31: 201-219$.

Kidd KK, Kidd JR. 1996. A nuclear perspective on human evolution. In: Boyce AJ, Mascie-Taylor CGN, editors. Society for the Study of Human Biology Symposium 38: Molecular biology and human diversity. Cambridge: Cambridge University Press. p 242264

Kirch PV. 1997. The Lapita people: Ancestors of the Oceanic world. Cambridge: Blackwells.

Kirch PV, Green RC. 1987. History, phylogeny and evolution in Polynesia. Curr Anthropol 28:431-456.

Kirch PV, Hunt TL. 1988. The spatial and temporal boundaries of Lapita. In: Kirch PV, Hunt TL, editors. Archaeology of the Lapita cultural complex: A critical review. Seattle: Thomas Burke Memorial Washington State Museum Research Report 5. p 9-31.

Kirk RL .1982. Linguistic, ecological and genetic differentiation in New Guinea and the Western Pacific. In: Crawford M, Mielke J, editors. Current developments in anthropological genetics, Vol II. New York: Plenum. p 229-254.

Kirk RL. 1992. Population origins in Papua New Guinea - A human biological overview. In: Attenborough $\mathrm{RD}$, Alpers MP, editors. Human biology in Papua New Guinea: The small cosmos. Oxford: Oxford Science Publications. p 172-197.

Kittles RA, Bergen AW, Urbanek M, Virkkunen M, Linnoila M, Goldman D, Long JC. 1999. Autosomal, mitochondrial, and Y; chromosome DNA variation in Finland: evidence for a male-specific bottleneck. Am J Phys Anthropol 108:381-99.

Lee HS, Sambuughin N, Cervenakova L, Chapman J, Pocchiari M, Litvak S, et al. 1999. Ancestral origins and worldwide distribution of the PRNP 200K mutation causing familial Creuzfeldt-Jakob disease. Am J Hum Genet 64:1063-70.

Long, J, Naidu J, Mohrenweiser H, Gershowitz H, Johnson P, Wood J, Smouse P. 1986. Genetic characterization of the Gainj and Kalam speaking peoples of Papua New Guinea. Am J Phys Anthropol 70:75-96.

Lum JK, Cann RL. 1998. mtDNA and language support a common origin of Micronesians and Polynesians in Island Southeast Asia. Am J Phys Anthropol 105:109119.

Lum JK, Cann RL, Martinson JJ, Jorde LB. 1998. Mitochondrial and nuclear genetic relationships among Pacific Island and Asian populations. Am J Hum Genet 63:613-624.

Lum K, Richards O, Change C, Cann RL. 1994. Polynesian mitochondrial DNA's reveal three deep maternal lineage clusters. Hum Biol 66:567-590.

Macaulay V, Richards M, Hickey E, Vega E, Cruciani F, Guida V, Scozzari R, Bonne-Tamir B, Sykes B, Torroni A. 1999. The emerging tree of west Eurasian mtDNAs: A synthesis of control-region sequences and RFLPs. Am J Hum Genet 64:232-249.

Malaspina P, Cruciani F, Ciminelli M, Terrenato L, Santolamazza P, et al. 1998. Network analyses of Y-chromosomal types in Europe, Northern Africa, and 
Western Asia reveal specific patterns of geographic distribution. Am J Hum Genet 63:847-60.

Marks J. 1995. Human biodiversity: Genes, race, and history. New York: Aldine.

Martinson JJ. 1996. Molecular perspectives on the colonization of the Pacific. In: Boyce AJ, Mascie-Taylor CGN, editors. Society for the Study of Human Biology Symposium 38: Molecular biology and human diversity. Cambridge: Cambridge University Press. p $171-$ 195.

Martinson JJ, Boyce AJ, Clegg JB. 1994. VNTR alleles associated with the alpha globin locus are haplotype and population related. Am J Hum Genet 55.513-25.

Mazzur S, Burgert S, Blumberg BS, 1973a. Geographic distribution of Australia antigen determinants d, y, and "w." Nature 247:38-40.

Mazzur S, Falker D, Blumberg BS. 1973b. Geographical variation of the "w" subtype of Australia antigen. Nature New Biol 243:-47.

Melton T, Clifford S, Martinson J, Batzer M, Stoneking M. 1998. Genetic evidence for the Proto-Austronesian homeland in Asia: mtDNA and nuclear DNA variation in Taiwanese aboriginal tribes. Am J Hum Genet 63:1807-23.

Melton T, Peterson R, Redd AJ, Saha N, Sofro ASM, Martinson J, Stoneking M. 1995. Polynesian genetic affinities with Southeast Asian populations identified by mtDNA analysis. Am J Hum Genet 57:403-414.

Merriwether DA. 1998. Freezer anthropology: New uses for old DNA: Examples from the New World and the Pacific. Phil Trans Roy Soc B 354:121-129.

Merriwether DA, Clark AG, Ballinger SW, Schurr TG Soodyall H, Jenkins T, Sherry ST, Wallace DC. 1991. The structure of human mitochondrial DNA variation. J Molec Evol 33:543-555.

Merriwether DA, Huston SL, Bunker CA, Ferrell RE. 1994. Origins and dispersal of the mitochondrial DNA region $\mathrm{V}$ 9-bp deletion and insertion in Nigeria and the Ivory Coast. Am J Hum Genet 55(3):A158.

Merriwether DA, Hall W, Vahline A, Ferrell RE. 1996. mtDNA variation indicates Mongolia may have been the source for the founding population for the New World. Am J Hum Genet 59:204-212.

Merriwether DA, Kaestle FA, Zemel B, Koki G, Mgone C, Alpers M, Friedlaender J. 1999. Mitochondrial DNA variation in the Southwest Pacific. In: Papiha SS, Deka R, Chakraborty R, editors. Genomic diversity: Applications in human population genetics. New York: Plenum Publishers (in press).

Mitchell DD, Nash J, Ogan E, Ross H, Bayliss-Smith T, Keesing RM, Gillogly Aikin K, Friedlaender J. 1987. Profiles of the survey samples In: Friedlaender JS, editor. The Solomon Islands Project: A long term study of human biology and culture change. Oxford: Oxford Science Publications.

Moore CC, Romney AK. 1994. Material culture, geographic propinquity and linguistic affiliation along the north coast of New Guinea: A reanalysis of Welsch, Terrell and Nadolski (1992). Am Anthropol 96:370 392 .

Moore CC, Romney AK. 1996. Will the "real" data please stand up? Reply to Welsch (1996). J Quant Anthropol 6:235-261.

Oliver DL. 1989. Oceania: The native cultures of Australia and the Pacific Islands. Honolulu: University of Hawaii Press.

Nei, M. 1972. Genetic distance between populations. Am Naturalist 106:283-292.

Pavlides C, Gosden C. 1994. 35,000 year-old sites in the rain forests of West New Britain, Papua New Guinea. Antiquity 69: 604-610.

Pawley AK, Green RC. 1973. Dating the dispersal of the Oceanic languages. Oceanic Ling 12:1-67.
Pawley AK, Ross M. 1993. Austronesian historical linguistics and culture history. Annu Rev Anthropol 22:425-459.

Pawley AK, Ross M. 1995. The prehistory of the Oceanic languages: A current view. In: Bellwood P, Fox JJ, Tryon D, editors. The Austronesians: Historical and comparative perspectives. Canberra: Australian National University (Department of Anthropology). p39-95.

Pietrusewsky M. 1977. Etudes des relations entre les populations du Pacifique par les methodes d'analyse multivariee appliquees aux variations craniennes. L'Anthropol 81:67-97.

Redd AJ, Takezaki N, Sherry ST, McGarvey ST, Sofro ASM, Stoneking M. 1995.Evolutionary History of the COII/tRNA ${ }^{\text {Lys }}$ intergenic 9 base pair deletion in human mitochondrial DNAs from the Pacific. Molec Biol Evol 12:604-615.

Reich DE, Goldstein DB. 1998. Genetic evidence for a Paleolithic human population expansion in Africa. Proc Natl Acad Sci USA 95(14):8119-8123.

Rhoads JG, Friedlaender JS. 1987. Blood polymorphism variation in the Solomon Islands. In: Friedlaender JS, editor. The Solomon Islands Project: A long-term study of health, human biology, and culture change. Oxford: Clarendon. p 125-154.

Roberts RG, Jones R, Smith MA. 1994. Beyond the radiocarbon barrier in Australian prehistory. Antiquity 69:611-616.

Roberts JM Jr, Moore CC, Romney AK. 1995. Predicting similarity in material culture among New Guinea villages from propinquity and language: a log-linear approach. Curr Anthropol 36:769-788.

Rogers A, Harpending H. 1983. Population structure and quantitative characters. Genetics 105:985-11002.

Saiki RK, Glefland DH, Stoffel S, Scharf SJ, Higuchi R, Horn GT, Mullis KB, Erlich HA 1988. Primerdirected enzymatic amplification of DNA with a thermostable DNA polymerase. Science 239:487-491.

Saitou N. 1996. Contrasting gene trees and population trees of the evolution of modern humans. In: Boyce AJ, Mascie-Taylor CGN, editors. Society for the Study of Human Biology 38. Molecular biology and human diversity. Cambridge: Cambridge University Press. p 265-282.

Schanfield MS. 1977. Population affinities of the Australian Aborigines as reflected by the genetic markers of immunoglobulins. J Hum Evol 6:341-352.

Serjeantson S, Gao X. 1995. Homo sapiens is an evolving species: Origins of the Austronesians. In: Bellwood P, Fox JJ, Tryon D, editors. The Austronesians: Historical and comparative perspectives. Canberra: Australian National University (Department of Anthropology). p 17-38.

Serjeantson S, Kirk RL, Booth PB. 1983. Linguistic and genetic differentiation in New Guinea. J Hum Evol 12(1):77-92.

Serjeantson SW, Board, Bhatia K. 1992. Population genetics in Papua New Guinea. In: Attenborough R, Alpers MP, editors. Human biology in Papua New Guinea: The small cosmos. Oxford: Oxford Science Publications. p 198-233.

Sokal R, Friedlaender JS. 1982. Spatial autocorrelation analysis on biological variation on Bougainville Island. In: Crawford M, Mielke J, editors. Current developments in anthropological genetics: Ecology and population structure, Vol. 2. New York: Plenum Press. p 205-215.

Soodyall H, Jenkins T, Hewitt R, Krause A, Stoneking M. 1996. The peopling of Madagascar. In: Boyce AJ, Mascie-Taylor CGN, editors. Society for the Study of Human Biology 38. Molecular biology and human 
diversity. Cambridge: Cambridge University Press. p $156-170$.

Soodyall H, Vigilant L, Hill AV, Stoneking M, Jenkins T. 1996. mtDNA control region sequence variation suggests multiple independent origins of an "Asianspecific" 9-bp deletion in Sub-Saharan Africans. Am J Hum Genet 58:595-608.

Spriggs MJT. 1990. Dating Lapita: another view. In: Spriggs MJT, editor. Lapita design, form and composition: Proceedings of the Lapita Design Workshop. Canberra, Australia. Occasional Papers in Prehistory 19. p. $134-42$.

Spriggs MJT. 1996. What is Southeast Asian about Lapita? In: Akazawa T, Szathmary E, editors. Prehistoric Mongoloid dispersals. Oxford: Oxford University Press. p 324-348.

Spriggs MJT. 1997. The Island Melanesians. Cambridge, MA: Blackwell Publishers.

Stephens JC, Reich DE, Goldstein DB, Shin HD, Smith MW, et al. 1998 Dating the origin of the CCR5-delta32 AIDS-resistance allele by the coalescence of haplotypes. Am J Hum Genet 62: 1507-1515.

Stoneking M, Jorde LB, Bhatia K, Wilson AC. 1990. Geographic variation in human mitochondrial DNA from Papua New Guinea. Genetics 124:717-733.

Stoneking M, and Wilson AC (1989) Mitochondrial DNA. In: Hill A, editor. The colonization of the Pacific: A genetic trail. Oxford: Clarendon. p 215-245.

Swadling P, Chappell J, Francis G, Araho N, Ivuyo B. 1989. A late Quaternary Inland Sea and early pottery in Papua New Guinea. Archaeol Oceania 24(3):106109.

Sykes B, Lieboff A, Low-Beer J, Tetznere S, Richards M. 1995. The origins of the Polynesians: An interpretation from mitochondrial lineage analysis. Am J Hum Genet 57:1463-1475

Sykes B, Corte-Real H, Richards M. 1996. Palaeolithic and neolithic contributions to the European mitochondrial gene pool. In: Boyce AJ, Mascie-Taylor CGN, editors. Society for the Study of Human Biology 38. Molecular biology and human diversity. Cambridge: Cambridge University Press. p 130-140.

Terrell JE. 1977. Geographic systems and human diversity in the North Solomons. World Archaeol 9:72-81.

Terrell JE. 1989. What Lapita is and isn't. Antiquity 63:623-626.

Terrell JE, Fagan J. 1975. The savage and the innocent: sophisticated techniques and naive theory in the study of human population genetics in Melanesia. Yrbk Phys Anthrop 19:1-18.

Terrell JE, Welsch RL. 1990. Trade networks, areal integration, and diversity along the north coast of New Guinea. Asian Perspect 29(2):156-195.

Terrell JE, Welsch RL. 1997. Lapita and the temporal geography of prehistory. Antiquity.71:548-572.

Torroni A, Bandelt HJ, D'Urbano L, Lahermo P, Moral P, Sellitto D, Rengo C, Forster P, Savontaus ML, BonneTamir B, Scozzari R. 1998. mtDNA analysis reveals a major late Paleolithic population expansion from southwestern to northeastern Europe. Am J Hum Genet 62:1137-52.

Turner CG II. 1990. Major features of Sunadonty and Sinodonty including suggestions about East Asian microevolution, population history, and late Pleistocene relationships with Australian Aboriginals. Am J Phys Anthropol 82:295-317.

van Holst Pellekaan, Frommer M, Sved J, Boettcher B. 1998. Mitochondrial control-region sequence variation in aboriginal Australians. Am J Hum Genet 62:435-49.

Ward RH. 1996. Linguistic divergence and genetic evolution: A molecular perspective from the New World. In: Boyce AJ Mascie-Taylor CGN, editors. Society for the Study of Human Biology 38. Molecular biology and human diversity. Cambridge: Cambridge University Press. p 205-224.

Warner JN. 1962. Sugar cane: An indigenous Papuan cultigen. Ethnology 1:405-411.

Welsch RI, Terrell JE, Nadolski JA. 1992. Language and culture on the north coast of New Guinea. Am Anthropologist 94:568-600

Wickler S, Spriggs M. 1988. Pleistocene human occupation of the Solomon Islands, Melanesia. Antiquity 62:703-706.

White JP, Allen J, Specht J. 1988. Peopling the Pacific: The Lapita Homeland Project. Austral Nat Hist 22: 410-416.

Wurm SA. 1975. The East Papuan phylum in general. In: Wurm SA, editor. Papuan languages and the New Guinea linguistic scene. Canberra: Department of Linguistics, Research School of Pacific Studies, Australian National University. Pacific Linguistics C-38. p 783-804.

Yanagihara R. 1994. Geographic-specific genotypes or prototypes of human T-cell lymphotropic virus type 1 as markers for early and recent migration of human populations. Advan Virus Res 43:147-186.

Yen DE. 1992. Polynesian cultigens and cultivars: The questions of origin. In: Cox PA, Banack SA, editors. Islands, plants and Polynesians: An introduction to Pacific ethnobotany. Portland: Dioscorides Press. p $67-95$. 